\author{
UNITED STATES \\ DEPARTMENT OF THE INTERIOR
}

GEOLOGICAL SURVEY

\title{
PALYNOLOGY OF THE LOWER CRETACEOUS PEBBLE SHALE UNIT, POINT BARROW, ALASKA
}

\section{By}

Timothy A. Timmcke

\author{
OPEN-FILE REPORT No. 81-1304
}

This report is preliminary and has not been reviewed for conformity with Geological Survey editorial standards and stratigraphic nomenclature. 



\begin{abstract}
Thirteen samples were analyzed for their palynomorph content from a $128 \mathrm{~m}$ cored section (informally named the "Pebble Shale Unit") of the South Barrow Test Well No. 2 drilled by the United States Geological Survey in the National Petroleum Reserve Alaska (NPRA) southeast cf Point Barrow, the northernmost region in Alaska.

Chemical maceration of these samples from the "Pebble Shale Unit" yielded approximately 61 genera and 91 species of spores and pollen; of this total, 41 genera and 64 species are pteridophyte spores and 18 genera and 25 species represent pollen of gymnosperms. Two angiosperm pollen species were recovered.

The geologic age of the "Pebble Shale Unit" is dated here as belonging to the Barremian and Hauterivian Stages of the Lower Cretaceous, based primarily on the presence of several guide fossil species of marine dinoflagellate cysts. The assemblage of terrestrially derived palynomorphs revealed in the present investigation substantiates this age. The combination of foraminifera, dinoflagellates, acritarchs, pelecypods, pteridophyte spores, and gymnosperm pollen occurring in the "Pebble Shale Unit" of the South
\end{abstract}


Barrow Test Well No. 2 is regarded as reliable evidence of a nearshore marine (paralic) origin for sediments of this unit during the time of deposition in the early Cretaceous. 


\section{ACKNOWLEDGMENTS}

I want to thank Dr. James E. Canright for review and criticism of this manuscript, and also for the academic opportunity to study palynology.

I thank Drs. W. Dennis Clark and L. P. Knauth for serving as members of my graduate committee and for reviewing this thesis.

I also wish to thank Roger J. Witmer, Geologist, office of the National Petroleum Reserve Alaska (Menlo Park, California), for making the Point Barrow Test Well No. 2 core samples available, as well as for bis advice and support during the course of this investigation. 
TABLE OF CONTENTS

Page

LIST OF GENERA . . . . . . . . . . . . . . . . . viii

LIST OF TABLES . . . . . . . . . . . . . . . xii

LIST OF ILLUSTRATIONS . . . . . . . . . . . . . xiii

INTRODUCTION . . . . . . . . . . . . . . . 1

Objectives of the Investigation . . . . . . . 4

MATERIALS AND METHODS . . . . . . . . . . . 5

Sample Selection. . . . . . . . . . . . 5

Sample Preparation . . . . . . . . . . . 5

Sample and Slide Coding . . . . . . . . . 5

Sample Analysis . . . . . . . . . . . 6

Photography . . . . . . . . . . . . . 6

GEOLOGICAL OUTLINE . • . . . . . . . . . . . . . . . 7

Lithology of the Pebble Shale . . . . . . . 8

Previous Age Determinations of the Pebble Shale . 9

Depositional History of the Barrow Area . . . . 12

RESULTS OF THE PALYNOLOGICAL INVESTIGATION . . . . . . 16

Age of the Pebble Shale . . . . . . . . . 16

Composition of the Pebble Shale Microflora . . . 17

Marine vs. Terrestrial Influence on the

Pebble Shale... . . . . . . . . . 25 
SUMMARY AND CONCLUSIONS . . . . . . . . . . . . 29

SYSTEMATIC DESCRIPTIONS . . . . . . . . . . 30

Spores .................. 30

Gymnospermic Pollen . . . . . . . . . . 71

Angiospermic Pollen ............. 88

Literature CITED . . . . . . . . . . . . 108 
LIST OF GENERA

Page

Spores...................... 30

Genus Acanthotriletes Naumova 1939 ex Potonié and Kremp 1954 . . . . . . . . 30

Genus Aequitriradites Delcourt and

Sprumont 1955 emend. Cookson and

Dettmann 1961 ............ . 31

Genus Baculatisporites Thomson and Pflug 1953 . . . . . . . . . . . . . . 32

Genus Biretisporites Delcourt and Sprumont

1955 emend. Delcourt, Dettmann, and

Hughes 1963 . . . . . . . . . . . . . . 33

Genus Calamospora Schopf et al. 1944 . . . . 34

Genus Camarozonsporites Potonié 1956 emend. Klaus 1960 . . . . . . . . . . 35

Genus Ceratosporites Cookson and Dettmann

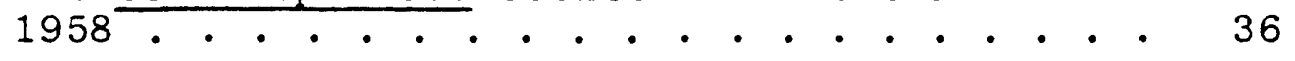

Genus Cicatricosporites Potonié and

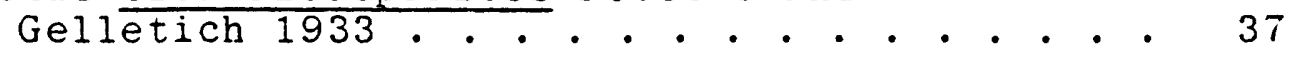

Genus Cingutriletes Pierce 1961 emend.

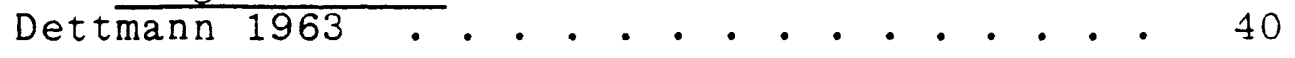

Genus Concavisporites Pflug 1953 emend. Delcourt and Sprumont 1955 . . . . . . . . . 42

Genus Concavissimisporites Delcourt and Sprumont 1955 emend. Delcourt et al. 1963 . . . . . . . . . . . . . .

Genus Converrucosisporites Potonié and Kremp 1954....... . . . . . . . . . 
Genus Couperisporites Pocock 1962 . . . . . 45

Genus Crybelosporites (Cookson and Dettmann) Dettmann 1963 . . . . . . . . 46

Genus Cyathidites Couper 1953. . . . . . . 46

Genus Deltoidospora Miner 1935 emend. Potonié 1956 . . . . . . . . . . . . . 47

Genus Densoisporites Weyland and Krieger 1953 emend. Dettmann 1963 . . . . . . . . 49

Genus Dictyophyliidites Couper 1958 emend.

Dettmann 1963 . . . . . . . . . . . 50

Genus Distalanulisporites Klaus 1960 . . . . 50

Genus Distaltriangulisporites Singh 1971 . . . 51

Genus Foraminisporis Krutzsch 1959 . . . . . 51

Genus Foveosporites Balme 1957 . . . . . . 52

Genus Gleicheniidites Delcourt and

Sprumont 1955 emend. Dettmann 1963 . . . 53

Genus Granulatisporites Ibrahim 1933 emend. Potonié and Kremp 1954 . . . . . . . 54

Genus Impardecispora Venkatachala et al. $1969 \cdot$ •................. 55

Genus Laevigatosporites Ibrahim 1933 emend. Schopf et al. 1944 . . . . . . . 55

Genus Leptolepidites Couper 1953 . . . . . 56

Genus Lycopodiacidites Couper 1953 emend. Potonié 1956 . . . . . . . . . 57

Genus Lycopodiumsporites Thiergart 1938

ex Delcourt and Sprumont 1955 . . . . . . 58

Genus Microreticulatisporites Knox 1950 emend. Bharadwaj 1955 . . . . . . . 60 
Genus Neoraistrickia Potonié 1956 . . . . . 60

Genus Ornamentifera (Bolkhovitina)

Bolkhovitina 1966 . . . . . . . . . . 62

Genus Osmundacidites Couper 1953 . . . . . 63

Genus Polycingulatisporites Simoncsics and Kedves 1961 emend. Playford and Dettmann 1965 . . . . . . . . . . . . 64

Genus Rogalskaisporites Danzé-Corsin and

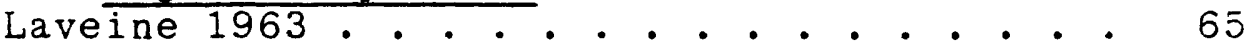

Genus Sestrosporites Dettmann 1963 . . . . . 65

Genus Stereisporites Pflug 1953 . . . . . . 66

Genus Tigrisporites Klaus 1960 emend. Singh $1971 . . \cdot$. . . . . . . . • . 67

Genus Todisporites Couper 1958 . . . . . . 68

Genus Undulatisporites Pflug 1953 . . . . . 68

Genus Verrucosisporites Ibrabim 1933 emend. Potonié and Kremp 1954 . . . . . . 69

Gymnospermic Pollen

Genus Abietineaepollenites Potonié 1951 ex Delcourt and Sprumont 1955 . . . . . . . 71

Genus Alisporites Daugherty 1941 restr. Potonié and Kremp 1956 . . . . . . . . . 72

Genus Araucariacites Cookson $1947 \mathrm{ex}$ Couper 1953 . • . . . . . . . . . 74

Genus Cedripites Wodehouse 1933 . . . . . . 74

Genus Cerebropollenites Nilsson 1958 . • • . 75

Genus Classopollis Pflug 1953 emend. Pocock and Jansonius 1961 . . . . . . . . 76 
Genus Equisetosporites Daugherty 1941 emend. Singh 1964 . . . . . . . . . . .

Genus Eucommiidites Erdtman 1948 emend. Hughes 1961 . . . . . . . . . . . . . 78

Genus Exesipollenites Balme 1957 . . . . . . 78

Genus Ginkgocycadophytus Samoilovich 1953 • • 79

Genus Gnetaceaepollenites Thiergart 1938 emend. Srivastava 1968 . . . . . . . . 80

Genus Inaperturopollenites Thomson and Pflug 1953 emend. Potonié 1958 . . . . . . 80

Genus Parvisaccites Couper 1958 . . . . . 82

Genus Perinopollenites Couper 1958 . . . . . 82

Genus Phyllocladidites Cookson 1947 ex Couper 1953 . . . . . . . . . . . . 83

Genus Podocarpidites Cookson 1947 ex Couper 1953 . . . . . . . . . . . . 84

Genus Rugubivesiculites Pierce 1961 .

Genus Vitreisporites Leschik 1955 emend. Jansonius 1962 . . . . . . . . . . . . 87 Angiospermic Pollen

Genus Clavatipollenites Couper 1958 . . . . 88 Genus Liliacidites Couper 1953 . . . . . . . 89 


\section{LIST OF TABLES}

Table

Page

1. Distribution and Relative Abundance of Spores and Pollen in the "Pebble Shale" 


\section{LIST OF ILLUSTRATIONS}

Figure

1. Index map of NPRA (formerly the Naval

Petroleum Reserve No. 4) in northern

Alaska, showing locations of test

wells and oil fields. . . . . . . . . . 2

2. Index map of the point Barrow area, showing core tests and test wells . . . . . 2

3. Stratigraphic column of the Lower

Cretaceous and older rocks of South

Barrow Test Well No. 2 . . . . . . . . .

4. Diagrammatic section showing Cretaceous

stratigraphic relations for northern

NPRA based on available paleontologic

and seismic data............. . . . 14

5. Graph of relative abundance relationships

of dinoflagellates, acritarchs, spores,

and bisaccate pollen based on a random

100-grain count per sample . . . . . . . 26

Plate

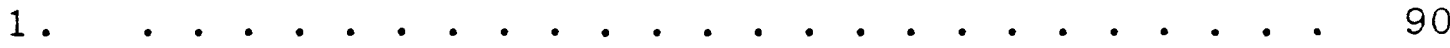

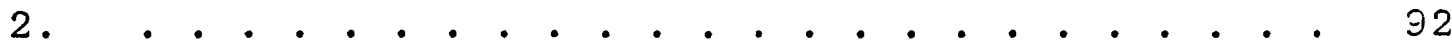

3. . . . . . . . . . . . . . . . . . 94

4. . . . . . . . . . . . . . . . . . . 96

5. • • • . . . . . . . . . . . . . . . . 98

6. . . . . . . . . . . . . . . . . . . 100

7 . . . . . . . . . . . . . . . . . 102

8. •....................... . 104

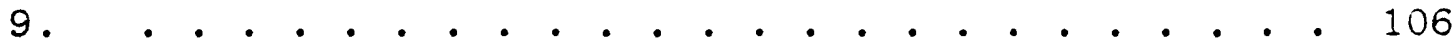




\section{NTRODUCTION}

During the span of years from 1944 to 1953, the United States Navy, United States Geological Survey, and Arctic Contractors Inc. coordinated a petroleum exploration program in the National Petroleum Reserve Alaska (NPRA; formerly called the Naval Petroleum Reserve No. 4) in nortbern Alaska. Test wells and core tests were drilled in many areas throughout the reserve to determine its geology, stratigraphy, and oil potential (Figure 1). The current palynological study involves Lower Cretaceous (HauterivianBarremian) sediments from one of these test wells, South Barrow Test Well No. 2, located five miles southeast of Point Barrow, Alaska (Figure 2).

The South Barrow Test Well No. 2 was selected for this investigation because it contained the most complete section in the Barrow area of the informally named "Pebble Shale" unit that has proved to be a key horizon for correlation of the subsurface geology of the NPRA, based on this unit's lithology and seismic records (Bird and Andrews 1979).

The exact geologic age of the "pebble shale" unit has been in dispute, with estimates ranging from the Tithonian Stage of the Upper Jurassic (Collins and Robinson 
Figure 1. Index map of NPRA (formerly the Naval Petroleum Reserve No. 4) in northern Alaska, showing location of test wells and oil fields (from Collins 1961).

Figure 2. Index map of the Point Barrow area, showing core tests and test wells (from Collins 1961). (Asterisk indicates locations of South Barrow Test Well No. 2.) 

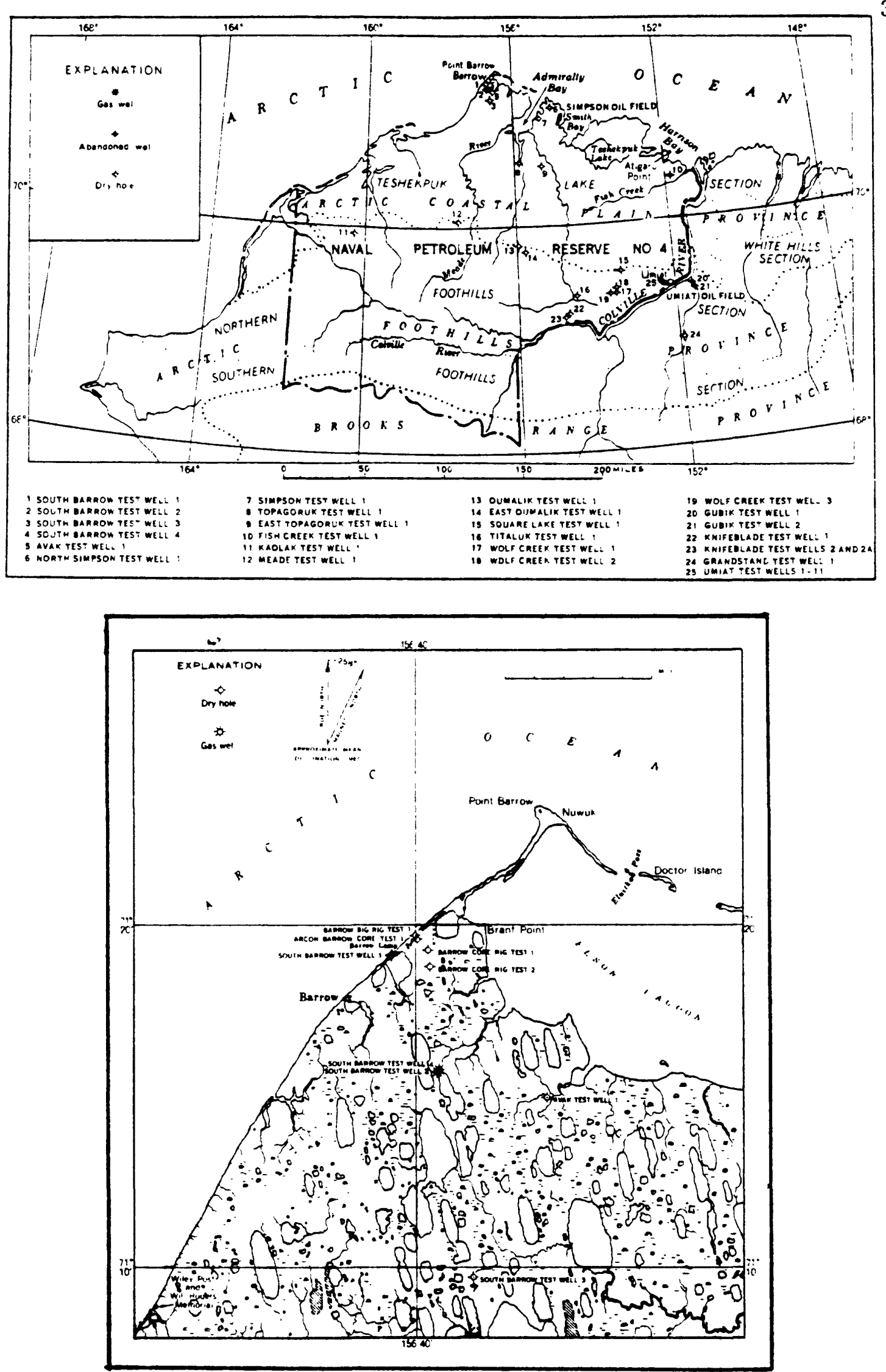
1967) to the Albian Stage of the Lower Cretaceous (Bergquist 1966).

Other than some confidential reports in the files of several petroleum companies, there is no information available concerning terrestrially derived fossil pollen and spores from the North Slope of Alaska. However, Wiggins (1973, 1975) and May (1979) have recently reported on marine dinoflagellates from Triassic to Lower Cretaceous horizons in the North Slope region.

The most pertinent palynological research on late Jurassic to early Cretaceous rocks of adjacent western Canada is that of Singh (1964, 1971), Norris (1967), and Pocock $(1962,1970)$.

Objectives of the Investigation

The objectives of this study are threefold: first, to compile a terrestrial palynological assemblage for the "Pebble Shale," with a very minor emphasis on dinoflagellate assemblages; second, to determine the age of the "pebble shale unit" using spores, pollen, and dinoflagellates; and third, to characterize the proportions of marine to terrestrial microfossils throughout this particular sedimentary unit. 


\section{MATERIALS AND METHODS}

\section{Sample Selection}

The United States Navy's 1948-1949 corings from Soutb Barrow Test Well No. 2 (So. Barrow T.W. 2) were sampled by personnel of the United States Geological Survey (USGS), Paleontology and Stratigraphy Branch, Denver, Colorado, and processed early in 1969. Samples were picked from lengths of core 20 feet and less, each core length being essentially of one lithology.

\section{Sample Preparation}

Standard USGS maceration techniques were employed:

HCl was used to dissolve carbonates, HF to dissolve silicates, and Schulze's solution $\left(\mathrm{HNO}_{3}+\mathrm{KClO}_{3}\right)$ to remove unnecessary organic compounds (Doher 1980). Slide mounts were prepared using Vinylite AYAF (refractive index 1.46) and Permount.

\section{Sample and Slide Coding}

Slide coding involves the USGS code number for So. Barrow T.W. 2 (D4033) followed by the specific USGS core code number (cores 32 through 59). Palynomorph specimens were coordinated for relocation using the distance in milimeters from left to right and front to back of the lower, left-hand corner of the coverslip. 
Sample Analysis

The USGS strewn slides were scanned under a light microscope at $400 x$, using a random 300-grain count for individual terrestrial palynomorph species frequencies. Anotber random $100-c o u n t$ was taken for relative abundance comparisons of acritarchs, dinoflagellates, spores, and bisaccate pollen grains to determine the amount of marine vs. terrestrial influence on the sediments involved.

Photography

The photography of the palynomorphs was done using a Leitz Orthomat automatic camera on a Leitz Ortholux microscope. Ilford Pan F film (50 ASA) was utilized and developed with Ilford Perceptol developer. The terrestrial palynoflora was photographed under bright field transmitted light. Photographs were enlarged to to either $1000 \mathrm{X}$ or $500 \mathrm{X}$ and printed on Kodak Polycontrast RC paper. 
GEOLOGICAL OUTLINE

Point Barrow is situated on the shore of the northernmost Arctic coastal plain in a lake-dotted tundra environment. Permafrost is the area's most noted feature, freezing the ground to a depth of 600 feet or more. While drilling South Barrow Test Well No. 2, the ground surface remained frozen during operations because driliing took place throughout the winter months of November, December, and January in the years $1948-1949$.

The Barrow area first attracted geological attention in 1946 when the United Geophysical Co., Inc., found an unusually high structural position of the strata in the area. A number of test wells were drilled in the vicinity, and South Barrow Test Well No. 2 was the first hole in the reserve to produce a significant amount of gas. The Barrow gas field, discovered by South Barrow Test Well No. 2, which penetrated to $763.5 \mathrm{~m}$, supplied gas as a source of heat for the Barrow camp, 5 miles to the north, from July 1949 until April 1950, when the well caught fire and was junked and abandoned. South Barrow Test Well No. 4 then replaced Test Well No. 2 as the source of gas for the camp.

South Barrow Test Well No. 2 was drilled in an area where seismic profiles outlined a small structural trap 
formed by faults defining a block of sediments that dip to the northwest (Collins 1961). The bole penetrated $21.3 \mathrm{~m}$ of marine Pleistocene sediments, $563.9 \mathrm{~m}$ of Cretaceous (Aptian-Albian) Torok Formation (a general stratigraphic term replacing the Topagoruk and Oumalik Formations), $121.9 \mathrm{~m}$ of Lower Cretaceous (Barremian-Hauterivian) "Pebble Shale," and $30.5 \mathrm{~m}$ of Jurassic Kingak Formation. The hole bottomed out in bluish-black argillite of pre-Mesozoic age. The gas flow in this well was presumed to be flowing from the Jurassic beds, but fractures in the pre-Mesozoic argilite also may have accounted for some of the gas (Collins 1961).

\section{Lithology of the Pebble Shale}

The "Pebble Shale" unit is composed of clay stone and clay shale of grayish-black color, containing abundant grains of pyrite, chert, and detrital quartz. The abundance of pyrite suggests a reducing environment, conducive to the preservation of organic matter. The quartz grains are predominantly very well-rounded, fine-grained to granular in size, and are pitted to polished (frosted) clear quartz (Collins et al. 1967). The unit receives its name from the very well-rounded gray and black randomly distributed chert grains that it contains, ranging in size from a medium sand to $6.4 \mathrm{~mm}$ diameter pebbles. In the Barrow area these 
chert pebbles form a basal conglomerate reaching $38 \mathrm{~mm}$ in diameter.

Figure 3 shows some selected lithologies of the "Pebble Shale" and its containing strata within South Barrow Test Well No. 2. Note the shows of oil and gas next to the stratigraphic column of the "Pebble Shale." Most of the shows of oil and gas appear where very thin, rare sandstone beds are found. The "pebble shale" is noted for its thin basal sandstone layers composed of angular or subangular clear quartz grains (as opposed to the rounded grains that are distributed throughout the shales and clay stone).

The "Pebble Shale" maintains a relatively constant thickness of about $100 \mathrm{~m}$ throughout the Arctic coastal plain and is easily correlated over long distances (Mull 1979).

Previous Age Determinations of the Pebbie Shale

Bergquist (1966) dated the "Pebble Shale" of South Barrow Test Well No. 2 as being early Albian in age and correlated the "Pebble Shale" with the lower part of the Torok Formation. His age determinations were based primarily on arenaceous foraminifera.

Collins et al. (1967) stated that the "Pebble Shale" may be as old as Oxfordian to Valanginian in the southern parts of the N.P.R.A. and that it grades into Early Albian age in the Barrow area to the north. 
Figure 3. Stratigraphic column of the Lower Cretaceous and older rocks of South Barrow Test Well No. 2 (after Collins 1961). 


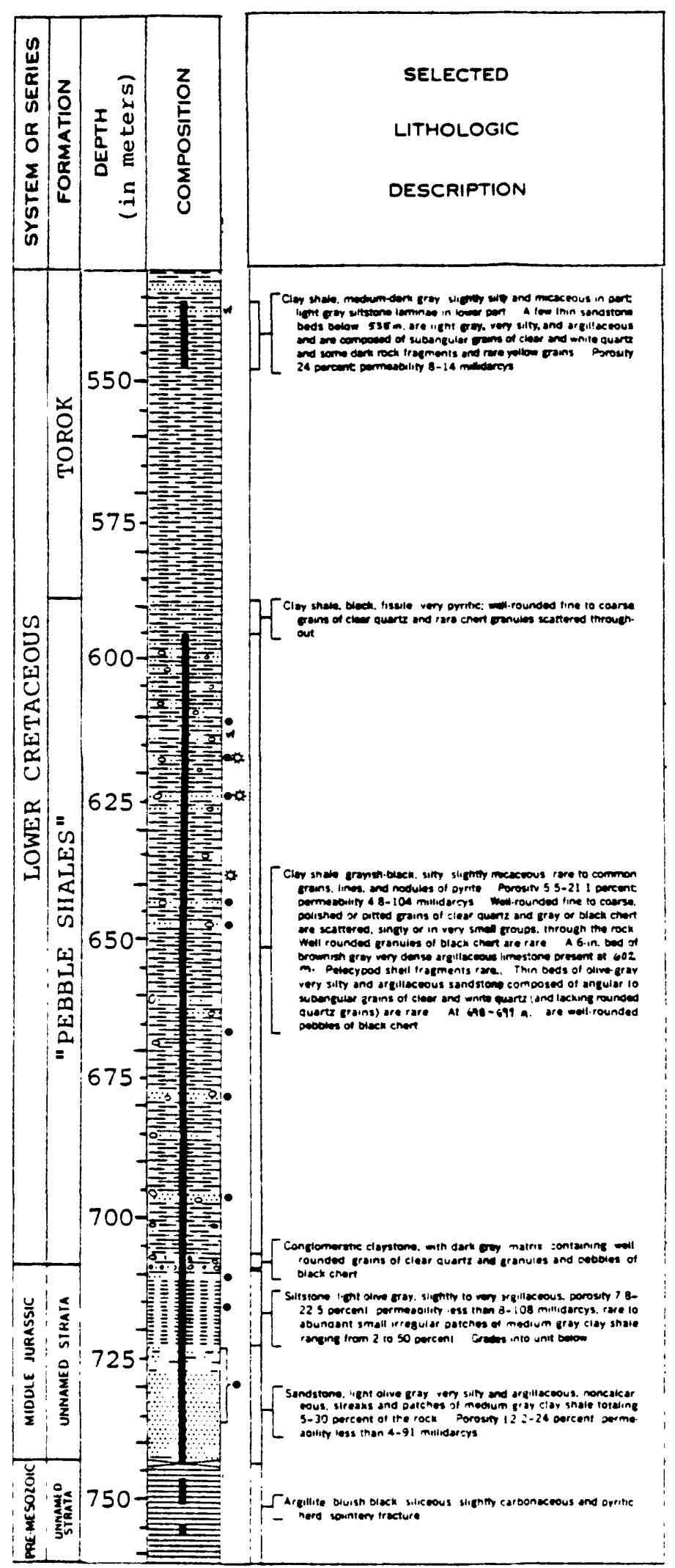

EXPLANATION

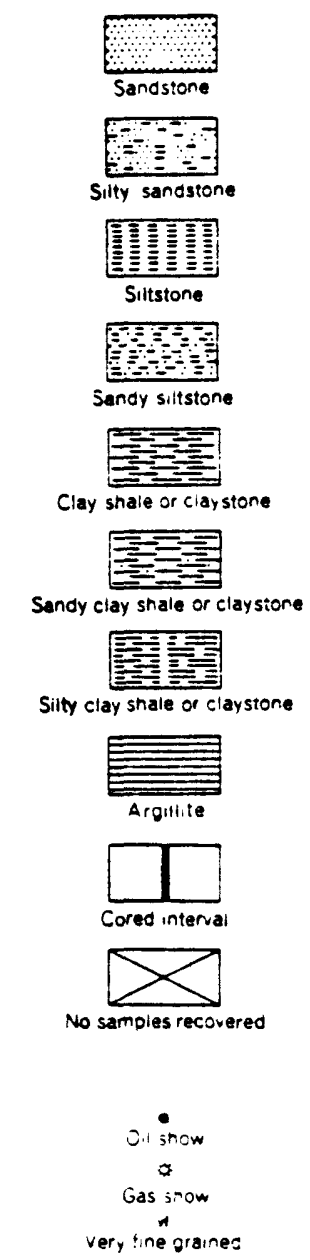

SOUTH BARROW TEST WELL 2

Location Lat $7 \cdot 15 \cdot 0 \times N$

Elevation Long $: 56^{\circ} 38000 \mathrm{~W}$

Geily busning $7.2 \mathrm{~m}$

Soudded: Ground $7.2 \mathrm{~m}, 10.5 \mathrm{~m}$

Completed April '5. 20

Completed April ' 5 , '

Status: Gas well, unnea 
Depositional History

of the Barrow Area

The following is a depositional sequence of the Barrow area that Collins et al. (1967) compiled from available geologic data:

1. Deposition and folding of the pre-Mesozoic bluish-black argillite, along with erosional beveling of the folded strata. Remnants of this weathered surface are preserved in a core from South Barrow Test Weli No. 1.

2. Deposition of Upper Triassic limestones, siltstones, and oolitic limonite along a shoreline in the vicinity of South Barrow Test Well No. 3 (the only Barrow well to penetrate such strata). The northern part of the Barrow area most likely was above sea level at this time.

3. Deposition accompanying a northward transgressing Jurassic sea, depositing successively younger beds to the north.

4. Deposition of the Lower Cretaceous "Pebble Shale" beds during complete inundation of the Barrow area, with the "Pebble Shale" being deposited on a relatively level surface underlain by pre-Mesozoic rocks to the north and Upper Jurassic beds to the south.

5. Deposition of the Aptian-Albian Torok Formation and Nanushuk Group rocks due to a prograding shoreline. Regional evidence suggests that these sediments (mostly shales) came from the south, being derived from positive (or 
high) areas created by the Cretaceous Brooks Range orogeny (Mull 1979). Bird and Andrews (1979) suggested that the Nanushuk Group and Torok Formation are lateral equivalents representing a single depositional system. Figure 4 illustrates this relationship. The Nanushuk Group and upper part of the Torok represent the topset seismic reflectors consisting of alluvial-deltaic and shelf deposits; the middle part of the Torok represents the foreset reflectors consisting of slope (marine) deposits; and the lower part of the Torok represents the bottomset reflectors consisting of basin-floor deposits (Bird and Andrews 1979).

6. Uplifting and faulting in the Barrow area forming the complex structures that create the structural traps where the Barrow gas field accumulated.

7. Erosional beveling of the Nanushuk Group and Torok Formation then removed any pre-Pleistocene deposits. 8. Deposition of marine Pleistocene sediments due to a Pleistocene transgressing sea from the north.

9. Retreat of the sea (regression) and subjection of the area to subaerial geologic processes to the present time. 
14

Figure 4. Diagrammatic section showing Cretaceous stratigraphic relations for northern NPRA, based on available paleontologic and seismic data (after Bird and Andrews 1979). 


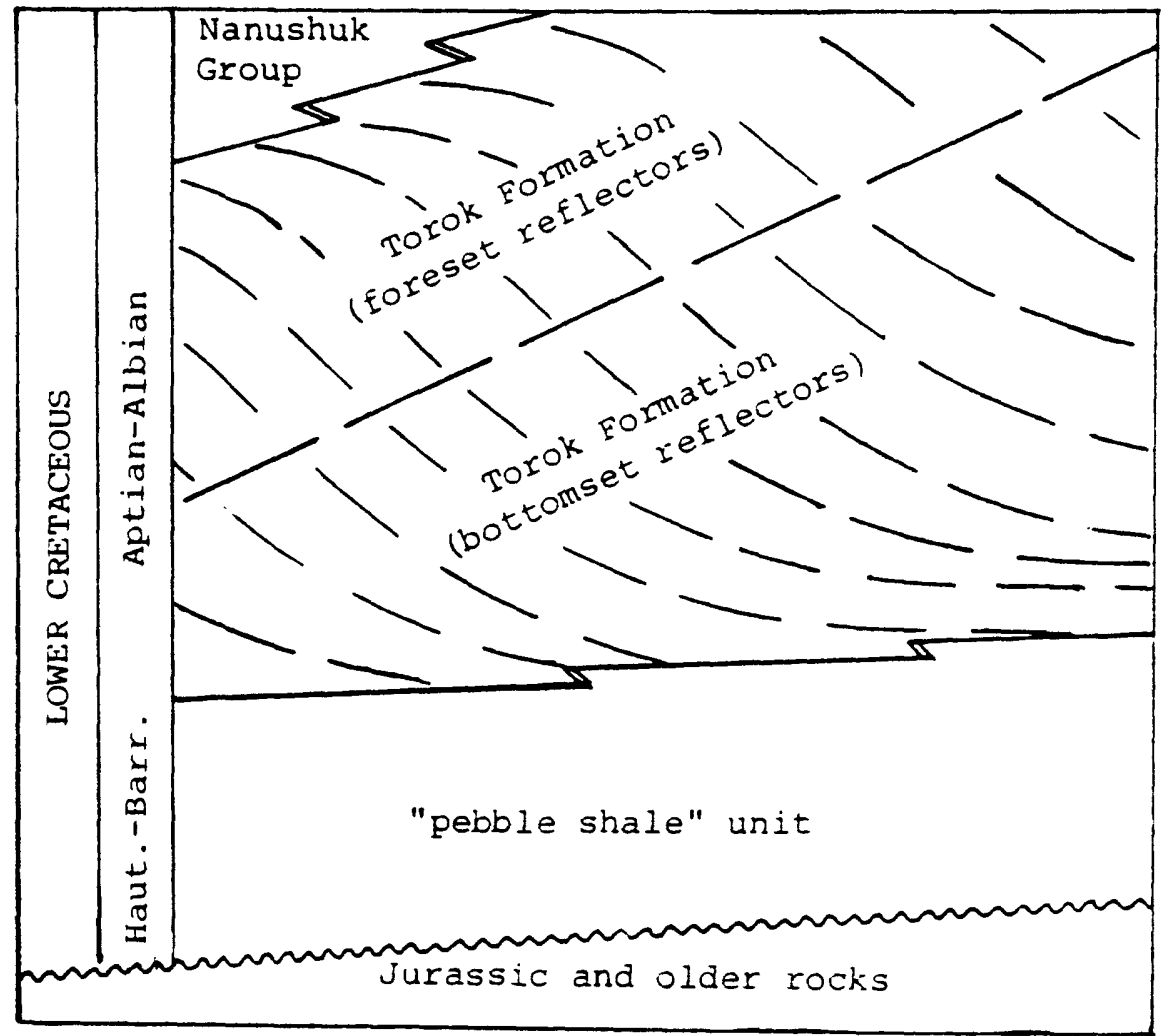


RESULTS OF THE PALYNOLOGICAL INVESTIGATION

Age of the Pebble Shale

The age of the "Pebble Shale" in Soutb Barrow Test Well No. 2 has been confirmed recently as being predominantly Barremian, with about $10 \mathrm{~m}$ of Hauterivian sediments at its base (Roger J. Witmer, 1981, personal communication). These ages have been assigned to the "pebble shale" through the use of marine dinoflagellate biostratigraphy.

The dinoflageliates that first appear in the Barremian are Aptea anaphrissa (Sarjeant) Sarjeant and Stover (1978), Cauca parva (Aberti) Davey and Verdier (1971), and Palaeoperidinium cretaceum Pocock (1962). These species can be traced down through the "Pebble Shale" to a depth of 701 meters and have ranges that extend into the Aptian and Albian.

Several species are confined to the "pebble shale" section and extend from 703.5 meters to the top of the "Pebble Shale" at a depth of 588 meters. These are: CasSiculosphaeridia magna Davey (1974) (with a known range of Berriasian to Barremian); Muderongia simplex Alberti (1961) (known range of Kimmeridgian to Barremian); and Oligosphaeridium asterigium (Gocht) Davey and Williams (1966) (known range of Valanginian to Barremian). Wallodinium krutzschi (Alberti) Habib (1972) (with a known range 
of Berriasian to Barremian) also is confined to the "Pebble Shale" and extends from a depth of 703.5 meters to 636.1 meters in South Barrow Test Well No. 2 .

Otber dinoflagellate species occurring above 703.5 meters in the South Barrow Test Well No. 2 cores are: Batiolodinium jaegeri (Alberti) Brideaux 1975 (1ate Hauterivian to Albian); Gardodinium trabeculosum (Gocht) Alberti (1961) (Hauterivian to Albian); Odontochitina operculata (Wetzel) Deflandre and Cookson (1955) (1ate Hauterivian to late Cretaceous); and Callaiosphaeridium asymmetricum (Deflandre and Courteville) Davey and Williams (1966) (Middle Hauterivian to Santonian).

The dinoflagellate aspects of the "Pebble Shale" will be discussed in greater detail in a forthcoming U.S. Geological Survey Professional Paper (Witmer, Wiggins, and Timmcke, in press).

Composition of the Pebble

Shale Microflora

The "Pebble Shale" unit of South Barrow Test Well No. 2 contains rich assemblages of both marine and terrestrial microfossils. This section of the manuscript concentrates on the terrestrially derived palynomorphs of the microflora. The "Pebble Shale" yielded a total of 91 species of spores and pollen belonging to 61 genera. Of these 91 species, 41 genera and 64 species are pteridophyte spores, 18 genera and 25 species are gymnospermous pollen, 
and the remaining two genera and species are of angiospermic affinity.

Pocock (1962) made a comprehensive study of the microflora from the Neocomian through middle Albian Manville Group of western Canada. Following is a list of species that Pocock (1962) found restricted to, or particularly abundant in, the Barremian strata of the Manville Group and also are found in the Barremian section of the "Pebble Shale." (A more complete citation of authors' names for these species can be found in the taxonomic list following the summary and conclusions.)

Biretisporites potoniaei

Cedripites caradensis

Couperisporites complexus

Deltoidospora psilostoma

Laevigatosporites ovatus

Parvisaccites radiatus

Podocarpidites multesimus

Todisporites minor

Verrucosisporites asymmetricus

Most of these species have ranges extending from the Upper Jurassic into the Albian, but whenever they are found in abundance, they are indicative of a Barremian age. Pocock (1962) did not find any Hauterivian sediments in the Manville group of western Canada. 
The following discussion concerns the specific composition of the "Pebble Shale" assemblage and places the species of pollen and spores into lists of occurrence within the age-bracketed sediments that the dinoflagellates dictate. The evidence from the dinoflagellates suggests that the age of the "Pebble Shale" is Barremian from a depth of $594 \mathrm{~m}$ to a depth of $701 \mathrm{~m}$, and Hauterivian from $701 \mathrm{~m}$ to $710 \mathrm{~m}$ in the South Barrow Test Well No. 2 (Roger J. Witmer, 1981, personal communication). Above $594 \mathrm{~m}$ is found the Aptian-Albian Torok Formation and below $710 \mathrm{~m}$ is found the Jurassic Kingak Formation, over which the "Pebble Shale" lies unconformably.

The distribution and relative abundances of each species encountered in the study samples are recorded in Table 1 .

The following lists comprise the terrestrial palynomorph assemblage found in the "Pebble Shale."

Those species found occurring only in the Barremian portion of the "Pebble Shale" are listed as:

Alisporites sp. A

Converrucosisporites sp. cf. C. exquisitus

Couperisporites complexus

Deltoidospora juncta

Impardecispora trioreticulosa

Microreticulatisporites diatretus

Neoraistrickia breviclavata 
aldues jad saijads 10 jaqunu jejol salejjes!a palel!uajall!pun

snp!lled samisodsiam!n

$\forall$ us salijodsisomija

snzujawixkse saluodsisoznuad

$\forall$ ds saj!jods!lejnpun

snjelnssol salijodsilempun jouide salijodsipo

snjeinaljas i. id de sajuodsisti sa!jisodsenb!lue sal!jodsiajais sniejoza/eopnasd $s$ ij ds salijodsojlsas $\forall$ ds sal!|njisasiqnбny sisojijejiz sailisodsieysiegoy

snaunpas $d \cdot \mathrm{d} \cdot \mathrm{ds}$ saujods $\forall$ ds sjup!djejopod snu/salinu sailpidjejopod snle/nue 6 salipidsejopod siuiroj!q sal!p!dsejopod $\forall$ ds salipipelooliर4

sapioleza saluallodouinad smieipes salizjesinje !!uew/lam sal!pizepunuso Eleulya ejaj!lluaweuso eleinjeq ejajiluaweuso $\forall \cdot d s$ eixjinsiejoan EjeJund eixoillsiejoan bienejonaja eixjilisigioan smianle!p sailjods!lejnilajom!n $\forall$ ds saltsodsunipodood sa!!sodswn/nomlas sai!sodsunipodoak snieuibjew sajusodswnipodoox salipileneivousne saiuodsunipodork $\forall$ ds salipizeipodook 7 $y$ ds salypizei!?

smiejnjaa 7 io ds salipidajoida 7 snjeno salljodsolebinap snlequn! salluallodo m!jadeul sniqno salivallodo jnyadeu esoinjilasoill esodsisapsedwi $\forall$ ds sallyods!le!nuesg $\forall$ ds salluallodacajelaug snj!vouas sa!!p!luayग!al salipiviosis salipinaujialg snpiliv snikudopejkoobxuig s!sejnouginians səlujodsoano$\forall$ ds s!jodsiviurejosnynun! salıallodisax jou!w soipp!lwuoगn s/suarivibjia saluodsolasinb $\forall \cdot d s$ sajuodsingueizlielsio snsojnjar saluodsuniverisio $\forall$ ds solpolikydoriud $\forall$ ds saiuodsiosuad ewolsolisd ejodsopiolla eljunl ejodsopiolla III/ey ejodsopiollad Joulu salipiylex\} sie»sie salipiuefo snajnuvea sajisodsojagরij snxaldwor saluodsijadnoj smisinbxa 0 . smieznisanuea salilod simissinezuoj snielound sallsodsiwissinezuoJ joulu salljodsiwissinezuoj $\forall$ ds sailiodsinejuoj

isadnos 0 io ds saliuallodileasio snsojol sillodosseio sap!ossejo sillodosseiv $\forall$ us sala!ıinbu!j

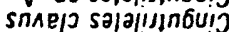

$\forall$.ds salilodsisojislezis

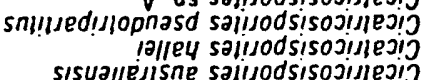

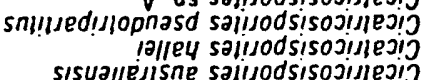
sisua!lejisne sailiodsisojillejij silsnine sajilodsisojillejis snieinuUe salijods!soj!llej!J snjiozosaw salivajiodosgasaj

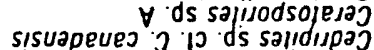
s!ubisui 3 io ds sallsodsovozojeweJ emozosau elodsowelea $\forall$ ds salusodsilang lapivolod sainodsilajig s!suawnewor sajuods!lejnoeg

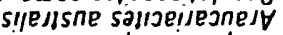
$\forall \cdot d s$ sajisodsity

snojesojoll salisodsil sipues6 salisodsily silesaleila salusodsily s!liqeijea $\forall j$ ds salipejulnba $\forall$ snsouids!jea sala!miouाueJ sisuapiaal salainlouluea

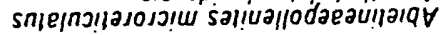
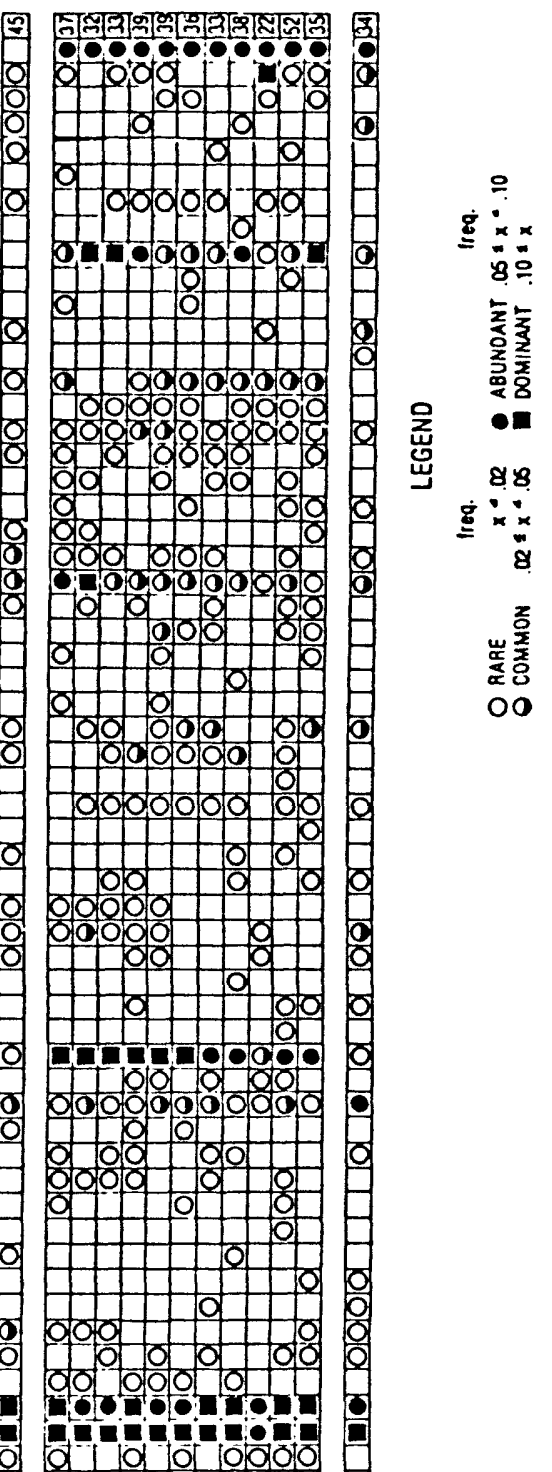

\section{政}

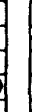

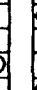

8

ㄱ.

.
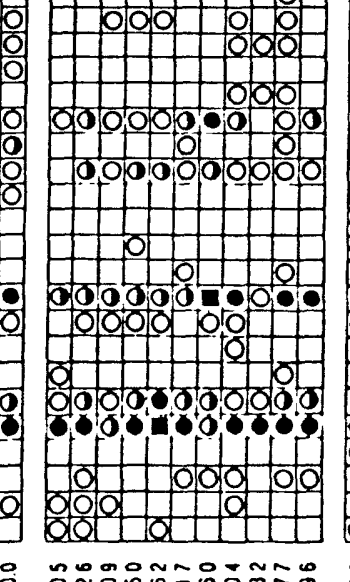

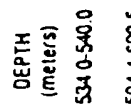

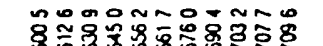

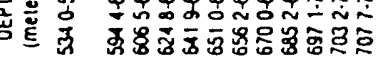

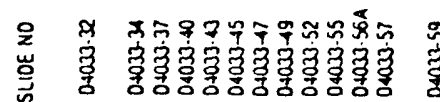


Rugubivesiculites sp. A

Tigrisporites $\mathrm{sp.} c f$. T. reticulatus

Undulatisporites fossulatus

Species baving an occurrence in the Hauterivian and Barremian "Pebble Shale," but not occurring above or below are listed as:

Acanthotriletes varispinosus

Alisporites microsaccus

Biretisporites potoniaei

Cicatricosisporites annulatus

Classopollis classoides

Clavatipollenites sp. cf. C. couperi

Concavissimisporites punctatus

Eucommiidites minor

Exesipollenites tumulus

Gleicheniidites circinidites

Neoraistrickia truncata

Neoraistrickia sp. A

Phyllocladidites sp. A

Podocarpidites multesimus

Sestrosporites $s p . c f . \underline{\text { S. pseudoalveolatus }}$

Species that were recorded in the Barremian "Pebble

Shale" and in the Aptian-Albian sample (D4033-32) are listed as:

Acanthotriletes levidensis

Cingutriletes sp. A 
Crybelosporites pannuceus

Distaltriangulisporites sp. A

Foveosporites subtriangularis

Laevigatosporites ovatus

Species that were recorded throughout the section but did not occur in the Jurasic sample (D4033-59) are Iisted as :

Alisporites grandis

A. grandis

Ceratosporites sp. A

Cicatricosisporites australiensis

C. hallei

Cicatricosisporites sp. A

Concavisporites sp. A

Cyathidites australis

Liliacidites sp. A

Lycopodiumsporites reticulumsporites

Ornamentifera baculata

Parvisaccites radiatus

Podocarpidites biformis

Todisporites minor

Undulatisporites sp. A

Verrucosisporites sp. A

Species that were recorded throughout the section but did not occur in the Aptian-Albian sample (D4033-32) are listed as: 
Abietineaepollenites microreticulatus

Biretisporites sp. A

Classopollis torosus

Dictyophyllidites sp. A

Foraminisporis sp. A

Granulatisporites sp. A

Leptolepidites sp. cf. L. verrucatus

Lycopodiumsporites austroclavatidites

Perinopollenites elatoides

Stereisporites antiquasporites

Of these 11 species, Stereisporites antiquasporites was particularly abundant throughout the samples.

Species that were encountered throughout all the samples, including the Aptian-Albian down through the Jurassic, are listed as:

Alisporites bilateralis

Araucariacites australis

Baculatisporites comaumensis

Cedripites sp. ci. C. canadensis

Cerebropollenites mesozoicus

Cingutriletes clavus

Cyathidites minor

Deltoidospora hallii

D. psilostoma

Densoisporites sp. A

Gleicheniidites senonicus 
Ginkgocycadophytus nitidus

Inaperturopollenites dubius

Inaperturopollenites turbatus

Lycopodiumsporites sp. A

Ornamentifera echinata

Osmundacidites wellmanii

Podocarpidites granulatus

Rogalskaisporites cicatricosis

Verrucosisporites asymetricus

Vitreisporites pallidus

Of these 21 species, the following were abundant throughout the section: Alisporites bilateralis, Cyathidites minor, Deltoidospora hallii, Gleicheniidites senonicus, and Ornamentifera echinata.

The following species occurred only in the Hauterivian samples (D4033-55 to D4033-57). An asterisk indicates that the species also occurred in the Jurassic sample ( D4033-59)

Cicatricosisporites pseudotripartitus

Concavissimisporites minor

C. variverrucatus

*Distalanulisporites verrucosis

Equisetosporites virginiaensis

Gnetaceaepollenites sp. A

Lycopodiacidites sp. A

Lycopodiumsporites marginatus 
Several species were found only in the Aptian-Albian sample (D4033-32) of the Torok Formation. Among those species are Camarozonosporites insignis, and Cicatricosisporites augustus.

Several species appeared to be restricted to the Jurassic sample, among which are Aequitriradites sp. cf. A. variabilis, Calamospora mesozoica, and Polycingulatisporites sp. cf. $\underline{\text { P. reduncus. }}$

Marine vs. Terrestrial

Influence on the

Pebble Shale

To determine the amount of marine vs. terrestrial influence on the "pebble shale" a 100-grain count was made for each sample, comparing relative abundance of acritarchs and dinoflagellates to that of the spores and bisaccate pollen. Text-Figure 5 shows a graph of the relative abundance of various types of palynomorphs throughout the "Pebble shale." It is evident from this graph that when the spore component increases, the dinoflagellate numbers decrease correspondingly, and the opposite relationship holds true also. This relationship could be reflecting a proximity to shoreline, but also may be due to a shift in origin of the clay sediments being deposited, such as a storm origin vs. a fluvial origin. Another feature of the graph worth noting is that in sample D4033-59 (Jurassic) the acritarchs become very abundant and the dinoflagellates are 
Figure 5. Graph of relative abundance relationships of dinoflagellates, acritarchs, spores, and bisaccate pollen based on a random 100-grain count per sample. 
FREQUENCY

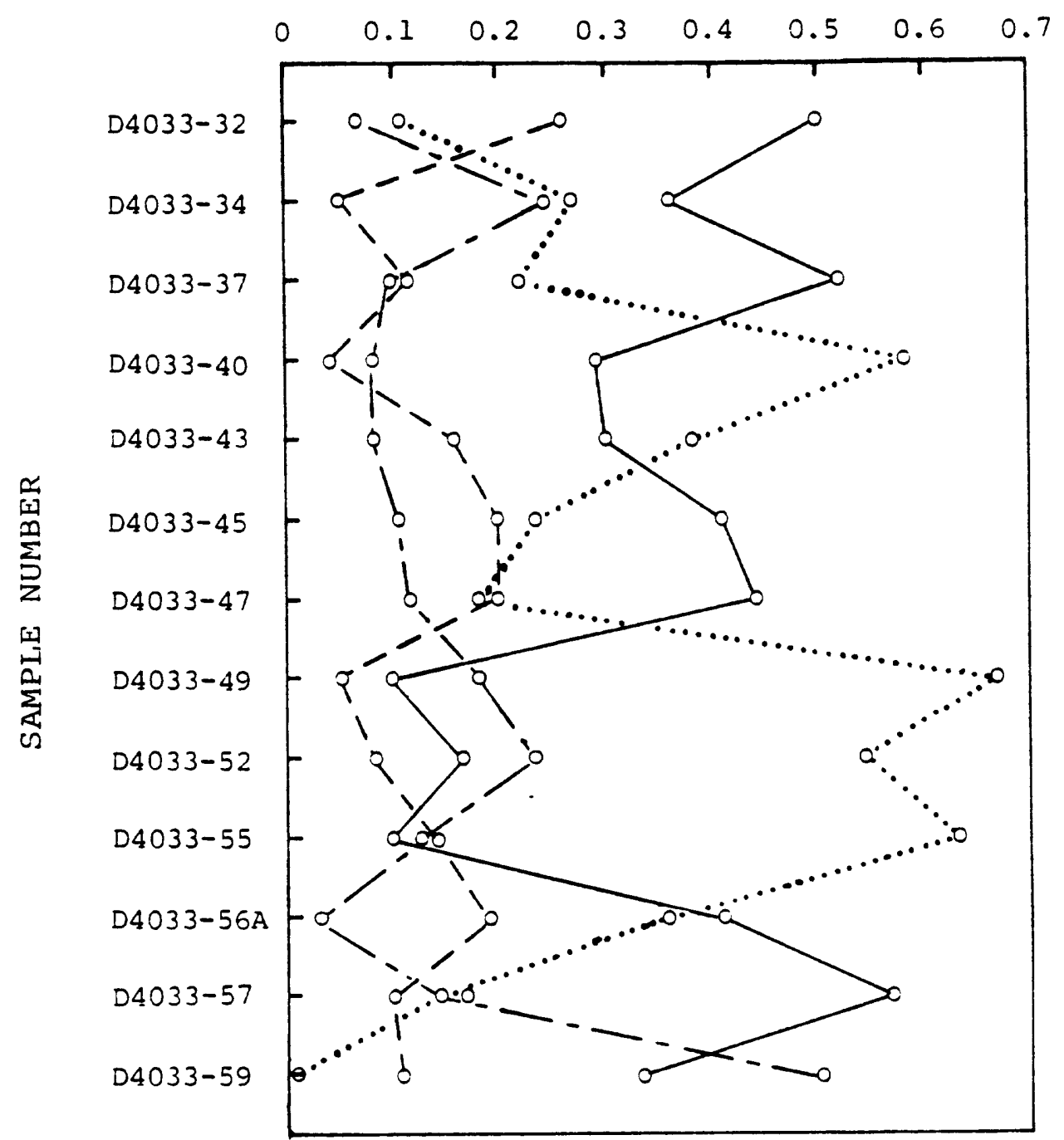

LEGEND

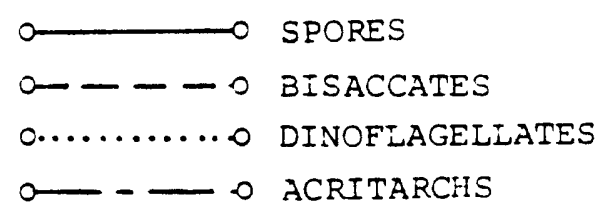


extremely scarce. This is evidence for the unconformity between the Hauterivian "Pebble Shale" beds and the Jurassic beds. 


\section{SUMMARY AND CONCLUSIONS}

Thirteen samples from the Lower Cretaceous sediments of South Barrow Test Well No. 2 were analyzed for palynomorph content. The "Pebble Shales" yielded a diverse assemblage of pollen and spores.

The following conclusions have been drawn from the palynological results presented in the preceding section:

1. The age of the "Pebble Shales" in South Barrow Test well No. 2 is predominantly Barremian, with a basal section of Hauterivian age, as dictated by the dinoflagellate assemblage involved.

2. The terrestrial pollen and spore assemblage indicates a Lower Cretaceous age of pre-Albian, because of the absence of angiosperm diversity. The terrestrial assemblage is analyzed further using the age definitions of the dinoflagellates as a basis for zonation.

3. The marine vs. terrestrial component of the microflora shows an inverse relationship between the dinoflagellates and the pollen and spores, most likely due to environmental origin of the clay sediments being deposited. 


\section{SYSTEMATIC DESCRIPTIONS}

Following is an alphabetical listing of genera and species of terrestrially derived palynomorphs recovered in this investigation arranged under the broad categories of spores, gymnospermic pollen, and angiospermic pollen.

\section{Spores}

Genus ACANTHOtRILetes Naumova ex Potonié and Kremp 1954

Type species: Acanthotriletes ciliatus Potonié and Kremp, 1954 .

See Singh (1964, p. 43) for synonymy and description of genus.

\section{Acanthotriletes levidensis Balme 1957}

Plate 1 , figures 1,2

Acanthotriletes levidensis Balme, Australia, C.S.I.R.O., Coal Res. Sect., Ref. T.C. 25, p. 18, p1. 1, figs. 18,19 .

See Singh (1964, p. 44) for synonymy and description.

DISTRIBUTION: Lower Cretaceous, Canada (Singh 1964 ) and Western Australia (Balme 1957). Barremian to Albian, this thesis. 
SIZE RANGE: Equatorial diameter 20 to 42 micrometers.

BOTANICAL AFFINITY: Family Selaginellaceae (Singh 1964).

Acanthotriletes varispinosus Pocock 1962

Plate 1 , figure 3

Acanthotriletes varispinosus Pocock, Palaeontographica, Band 111, Abt. B, p. 36, pl. 1, figs. 18-20.

See Singh (1964, p. 43) for synonymy and description. DISTRIBUTION: Lower Cretaceous. Worldwide geographic distribution. Barremian-Hauterivian, this thesis.

SIZE RANGE: Equatorial diameter 20 to $40 \mathrm{micro-}$ meters.

BOTANICAL AFFINITY: Family Selaginellaceae (Pocock 1962) .

Genus AEQUITRIRADITES Delcourt and Sprumont 1955, emend. Cookson and Dettmann 1961

Type species: Aequitriradites dubius Delcourt and Sprumont, 1955

See Singh ( 1964 , p. 88) for synonymy and description. 
Aequitriradites sp. cf. A. variabilis Pocock 1962 Plate 1 , figure 4

Aequitriradites variabilis Pocock, Palaeontographica, Band 111, Abt. B, p. 51, pl. 6, figs. 98-100.

See Singh (1964, p. 88) for synonymy and description. DISTRIBUTION: Lower Cretaceous. Reported from the Mannville Group (Neocomian to Middle Albian) of Western Canada (Pocock, 1962; Singh 1964). U. Jurassic, this thesis.

SIZE RANGE: Equatorial diameter (including zona) 68 micrometers (one specimen).

BOTANICAL AFFINITY: Class Hepaticae (Singh 1971).

Genus BACULATISPORITES Thomson and Pflug 1953 Type species: Baculatisporites primarius (Wolff) Thomson and Pflug 1953.

Baculatisporites comaumensis (Cookson) Potonié 1956

Plate 1, figures 5,6

Baculatisporites comaumensis (Cookson) Potonié, Teil:

Sporites; Beih. Geol. Jahrb., Heft 23, p. 33.

See Dettman (1963, p. 35) for synonymy and description.

DISTRIBUTION: Late Triassic to Cretaceous. Has a widespread geographic occurrence throughout the world. Jurassic to Albian, this thesis. 
SIZE RANGE: 27 to 65 micrometers in equatorial diameter.

BOTANICAL AFFINITY: Family Osmundaceae (Dettman 1963).

Genus BIRETISPORITES Delcourt and Sprumont 1955 , emend. Delcourt, Dettmann, and Hughes 1963

Type species Biretisporites potoniaei Delcourt and Sprumont, 1955.

See Delcourt, Dettmann, and Hughes (1963, p. 283) for synonymy and emended generic description.

Biretisporites potoniaei Delcourt and Sprumont 1955 Plate 1 figure 7

See Delcourt, Dettmann, and Hughes (1963, p. 284) for synonymy and description.

Biretisporites potoniaei Delcourt and Sprumont, Mém. Soc. Géol. Belgique, vol. 4, no. 5, pp. 40-41, fig. 10 .

DISTRIBUTION: Lower Cretaceous. Reported from the Lower Cretaceous of Alberta (Pocock 1962; Norris 1967; Singh 1971); Albian of Oklahoma, U.S.A. (Hedlund and Norris 1968); Lower Cretaceous of Belgium and France (Delcourt and Sprumont 1955, 1959), and Australia (Dettman 1963). BarremianHauterivian, this thesis.

SIZE RANGE: 35 to 50 micrometers. 
BOTANICAL AFFINITY: Family osmundaceae (Singh 1971).

\section{Biretisporites sp. A \\ Plate 1 , figure 8}

DESCRIPTION: Trilete; laesurae long, reaching almost to the equator; commissures raised, flanked by well developed margo; equatorial outline rounded triangular; sides convex, radial margins rounded. Exine granulose on both distal and proximal faces.

SIZE RANGE: Equatorial diameter 35 to 53 micrometers ( $t w o$ specimens).

DISTRIBUTION: This thesis, Barremian and Hauterivian. BOTANICAL AFFINITY: Family Osmundaceae (Singh 1971.

Genus CALAMOSPORA Schopf et al. 1944

Type species: Calamospora hartungiana Schopf et al. 1944. See Schopf et al. (1944, pp. 51-52) for generic diagnosis.

\section{Calamospora mesozoica Couper 1958}

Plate 1 , figure 10

Calamospora mesozoica Couper, Palaeontographica, Band 103, Abt. B, Leifg. 4-6, p. 132, pl. 15, fig. 3-4. See Pocock (1970) for synonymy and description.

DISTRIBUTION: Middle Jurassic. Reported from the middle Jurassic of Great Britain (Couper 1958) 
and western Canada (Pocock 1970). Jurassic, this thesis.

SIZE RANGE: 40 to 65 micrometers.

BOTANICAL AFFINITY: Couper (1958) places this spore in a group of probable kiesozoic calamitean affinity.

Genus CAMARozonosporites Potonié 1956, emend. Klaus 1960

Type species: Camarozonosporites cretaceus (Weyland and Krieger) Potonié 1956.

See Klaus (1960, p. 135) for emended generic diagnosis.

Camarozonosporites sp. cf. C. insignis Norris 1967

Plate 1 , figures 9,11

Camarozonsporites insignis Norris, Palaeontographica, Band 120, Abt. B, Leifg. 1-4, p. 96, pl. 13, figs. 12-16.

See Norris (1967, p. 96) for synonymy and description.

DISTRIBUTION: Albian and Cenomanian. Reported from the Albian and Cenomanian of Alberta (Norris 1967; Singh 1971); Maryland, U.S.A. (Brenner 1963 ); Oklahoma, U.S.A. (Hedlund and Norris 1968; Hedlund 1967); and of Colorado and viebraska, U.S.A. (Pannella 1966). Albian, this thesis. 
SIZE RANGE: 30 to 55 micrometers.

BOTANICAL AFFINITY: Singh (1971) places this species in the division Pterophyta, Incertae Sedis.

DISCUSSION: The specimens observed in this study may belong to the genus Lycopodiacidites, which possesses a rugulate sculpture, but lacks an interradial equatorial thickening.

Genus CERATOSPORITES Cookson and Dettmann 1958 Type species: Ceratosporites equalis Cookson and Dettmann 1958 .

See Cookson and Dettmann (1958, p. 101) for generic diagnosis.

\section{Ceratosporites sp. A}

$$
\text { Plate 2, figure } 1
$$

DESCRIPTION: Trilete; laesurae long, reaching almost to the equator; equatorial outline convexly subtriangular. Exine 1-1.5 micrometers thick, proximally smooth. Distal surface sculptured with nontapering elements with rounded apices, 2 to 3.5 micrometers long, 1 micrometer in width. Sculptural elements spaced 3.5 to 4 micrometers apart.

DISTRIBUTION: Neocomian-Aptian of Australia (type). Barremian, this thesis. 
SIZE RANGE: Equatorial diameter 35 to 45 micrometers. BOTANICAL AFFINITY: Uncertain. Cookson and Dettmann (1958) suggest affinity of type species with Selaginellaceae.

Genus CICATRICOSISPORITES Potonié and Gelletich 1933

Type species: Cicatricosisporites dorogensis Potonié and Gelletich 1933.

See Dettmann (1963, p. 52) for generic diagnosis.

Cicatricosisporites annulatus Archangelsky and Gamerro 1966

Plate 2, figures 2,3

Cicatricosisporites annulatus Archangelsky and Gamerro, Ameghiniana, vol. 4, p. 368 , pl. 2 , figs. 6-8.

See Singh (1971, p. 67) for synonymy and description. DISTRIBUTION: Cretaceous. Reported from the Lower Cretaceous of Alberta, Canada (Singh 1964, 1971); Cretaceous of Alberta, Canada (Norris 1967) and Argentina (Archangelsky and Gamerro 1966). Barremian-Hauterivian, this thesis.

SIZE RANGE: 35 to 45 micrometers.

BOTANICAL AFFINITY: Family Schizaeaceae (Singh 1971).

REMARKS: Although the specimens in this thesis are slightly smaller than those reported by Singh 
(1971), the rib patterning is comparable in both cases.

Cicatricosisporites augustus Singh 1971

Plate 2 , figures 4,5

Cicatricosisporites augustus Singh, Research Council of Alberta, Bull. 28, vol. 1, p. 68, pl. 7, figs. 3-11. See Singh (1971, p. 68) for description of species.

DISTRIBUTION: Albian of Alberta (Singh 1971). Albian, this thesis.

SIZE RANGE: 39 to 50 micrometers.

BOTANICAL AFFINITY: Family Schizaeaceae (Singh 1971).

Cicatricosisporites australiensis (Cookson)

Potonié 1956

Plate 2, figure 6

Cicatricosisporites australiensis (Cookson) Potonié, Teil:

Sporites; Beih. Geol. Jahrb., Heft 23, p. 48 .

See Dettmann (1963, p. 53) for synonymy and description.

DISTRIBUTION: Cretaceous. Widespread occurrence througbout various parts of the world. Hauterivian to Albian, this thesis.

SIZE RANGE: 40 to 65 micrometers.

BOTANICAL AFFINITY: Family Schizaeaceae (Singh 1971). 
Cicatricosisporites hallei Delcourt and Sprumont 1955

Plate 2, figure 7

Cicatricosisporites hallei Delcourt and Sprumont, Mém. Soc. Géol. Belgique, n.s., vol. 4, no. 5, p. 17 .

See Delcourt and Sprumont (1955, p. 17) for description.

DISTRIBUTION: Lower Cretaceous and Cenomanian.

Reported from various parts of central North America and from the "Wealden" of Belgium and

France (Delcourt and Sprumont 1955, 1959).

Hauterivian to Albian, this thesis.

SIZE RANGE: 33 to 60 micrometers.

BOTANICAL AFFINITY: Family Schizaeaceae (Singh 1971).

Cicatricosisporites pseudotripartitus (Bolkhovitina) Dettmann 1963

Plate 2, figure 8

Cicatricosisporites pseudotripartitus (Bolkhovitina) Dettmann, Proc. Roy. Soc. Victoria, 77, p. 54, pl. 10, figs. $1-5$.

See Dettmann (1963, p. 54) for synonymy and description.

DISTRIBUTION: Albian and Cenomanian. Reported from various geographical localities, including North America, Siberia, and Australia. Reported from the Barremian-Hauterivian of this thesis. 


\begin{abstract}
SIZE RANGE: 45 micrometers (two specimens). BOTANICAL AFFINITY: Dettmann (1963) also places this genus in the family Schizaeaceae.

REMARKS: Although this species has not been reported in horizons older than Albian, I have included my specimens in this species because they coincide with Dettmann's (1963) description.
\end{abstract}

Cicatricosisporites $\mathrm{sp}$. A

Plate 2, figure 9

DESCRIPTION: Trilete; laesurae almost reaching the equator; commissures simple slits; amb rounded-triangular; sides convex; apices rounded; proximal surface with 5 to 7 ribs in each interradial region about 1.5-2.0 micrometers wide; noncoalescing at the apices; ribs separated by a very narrow canal; exine thin, approximately 1 micrometer thick.

DISTRIBUTION: Hauterivian, this thesis.

SIZE RANGE: 37 micrometers ( $t$ wo specimens). BOTANICAL AFFINITY: Family Schizaeaceae.

Genus CINGUTRILETES Pierce 1961 emend. Dettmann 1963

Type species: Cingutriletes congruens Pierce 1961 
See Dettmann (1963, p. 69) for synonymy and emended generic diagnosis.

\section{Cingutriletes clavus (Balme) Dettmann 1963}

Plate 2, figures 10,11

Cingutriletes clavus Dettmann, Proc. Roy. Soc. Victoria, vol. 77, p. 69, pl. 14, figs. 5-8.

See Dettmann (1963, p. 69) for synonymy and description.

DISTRIBUTION: Jurassic to Tertiary. Widespread geographically throughout various parts of the world. Jurassic to Albian this thesis.

SIZE RANGE: 25 to 35 micrometers.

BOTANICAL AFFINITY: Family Sphagnaceae.

Cingutriletes $\mathrm{sp}$. A

Plate 2, figure 12

DESCRIPTION: Trilete; amb circular to subcircular; laesurae extending $2 / 3$ to equator; psilate exine; equatorial cingulum 2.5 micrometers wide.

DISTRIBUTION: Barremian to Albian. This thesis.

SIZE RANGE: 25 to 30 micrometers (two specimens). BOTANICAL AFFINITY: Family Sphagnaceae. 
Genus CONCAVISPORITES Pflug 1953 emend. Delcourt and Sprumont 1955

Type species: Concavisporites rugulatus Pflug 1953

See Potonié (1956, p. 15) for generic diagnosis.

\section{Concavisporites sp. A}

$$
\text { Plate } 3 \text {, figure } 1
$$

DESCRIPTION: Trilete; laesurae extending to equator; concave amb; exine smooth.

DISTRIBUTTION: Lower Cretaceous, this thesis.

SIZE RANGE: $23-32$ micrometers.

BOTANICAL AFFINITY: Pterophyta, Incertae Sedis.

Genus CONCAVISSIMISPORITES Delcourt and Sprumont 1955, emend. Delcourt et al. 1963

Type species: Concavissimisporites verrucosus Delcourt and Sprumont 1955, emend. Delcourt et al. 1963.

See Singh (1964, p. 76) for synonymy and generic diagnosis.

Concavissimisporites minor (Pocock) Delcourt et a 1. 1963

Plate 3 , figures 2,4

Concavissimisporites minor (Pocock) Delcourt et al., Palaeontology, vol. 6, p. 286.

See Singh (1971), p. 113) for synonymy and description. 
DISTRIBUTION: Upper Jurassic to Albian. Reported from Jurassic-Albian of western Canada (Pocock 1962; Singh 1971); Albian of Oklahoma, U.S.A. (Hedlund and Norris 1968). Hauterivian this thesis.

SIZE RANGE: 50 to 70 micrometers (two specimens) BOTANICAL AFFINITY: Pterophyta, Incertae Sedis.

Concavissimisporites punctatus (Delcourt and Sprumont) Brenner 1963

Plate 3 , figures 3,5

Concavissimisporites punctatus (Delcourt and Sprumont) Brenner, Maryland Dept. Geol. Mines Water Resources, Bul1. 27, p. 59, pl. 14, fig. 6 .

See Singh (1964, p. 77) for synonymy and description. DISTRIBUTION: Berriasian to Albian. Reported from the Lower Cretaceous of Canada, U.S.A., England, Belgium, Australia, U.S.S.R., and Rumania. Barremian-Hauterivian this thesis. SIZE RANGE: 50 micrometers. BOTANICAL AFFINITY: Pterophyta, Incertae Sedis.

Concavissimisporites variverrucatus (Couper) Brenner 1963

Plate 3 , figure 6 
Concavissimisporites variverrucatus (Couper) Brenner, Maryand Dept. Geol. Mines Water Resources, Bull. 27, p. 59, pl. 14, fig. 4 .

See Singh (1964, p. 78) for synonymy and description.

DISTRIBUTION: Middle Jurassic to Albian. Reported from the Albian of western Canada (Singh 1964, 1971); Lower Cretaceous of Maryland, U.S.A. (Brenner 1963); Albian of Wyoming (Davis 1963); Upper Jurassic-basal Cretaceous of England (Couper 1958). Hauterivian this thesis.

SIZE RANGE: 58 by 43 micrometers (one specimen). BOTANICAL AFFINITY: Pterophyta, Incertae Sedis.

Genus CONVERRUCOSISPORITES Potonié and Kremp 1954

Type species: Converrucosisporites triguetrus (Ibrahim) Potonié and Kremp 1954.

See Potonié and Kremp (1954, p. 63) for generic diagnosis.

Converrucosisporites sp. cf. C. exquisitus Singh 1971

Plate 3 , figure 7

Converrucosisporites exquisitus Singh, Res. Coun. Alberta, Bull. 15, p. 116, pl. 16, figs. 4-5. See Singh (1971, p. 116) for description. 
DISTRIBUTION: Albian of Alberta, Canada (Singh 1971). Barremian, this thesis.

SIZE RANGE: 60 micrometers (one specimen).

BOTANICAL AFFINITY: Pterophyta, Incertae Sedis.

REMARKS: Although this specimen has larger verrucae at the radial margins than in the interradial areas, the author did not feel this was sufficient cause for inclusion in the genus Trilobosporites.

Genus COUPERI SPORITES Pocock 1962

Type species: Couperisporites complexus (Couper) Pocock 1962 .

See Singh (1964, p. 83) for synonymy and generic diagnosis.

Couperisporites complexus (Couper) Pocock 1962 Plate 3 , figure 8

Couperisporites complexus (Couper) Pocock, Palaeontographica, Band 111, Abt. B, p. 50, pl. 6, figs. 91-94. See Singh (1964, p. 84) for synonymy and description.

DISTRIBUTION: Barremian to middle Albian. Reported from the Albian of Alberta, Canada (Singh 1964: Pocock 1962); Barremian of England (Hughes 1958); Barremian, this thesis.

SIZE RANGE: 60 micrometers (including zona). BOTANICAL AFFINITY: Class Hepaticae (Singh 1971). 
Genus CRYBELOSPORITES Dettmann 1963

Type species: Crybelosporites striatus (Cookson and Dettmann) Dettmann 1963 .

See Dettmann (1963, p. 80) for generic diagnosis.

\author{
Crybelosporites pannuceus (Brenner) Srivastava \\ 1975 \\ Plate 3 , figure 9
}

Crybelosporites pannuceus (Brenner) Srivastava, Paléobiologie continental, vol. 6 , no. 2 , p. 35 , pl. 15, figs. $5-9, \mathrm{pl} .16$, figs. 1-6.

See Srivastava (1975, p. 35) for synonymy; Brenner (1963, p. 66) for description.

DISTRIBUTION: Albian. Reported from the Albian of Maryland (Brenner, 1963), Oklahoma (Hedlund and Norris 1968), and the southern U.S.A. (Srivastava 1975). Barremian-Albian, this thesis. SIZE RANGE: 31 by $44 \mathrm{micrometers} \mathrm{(one} \mathrm{specimen).}$ BOTANICAL AFFINITY: Pterophyta, Incertae Sedis.

Genus CYATHIDITES Couper 1953

Type species: Cyathidites australis Couper 1953 .

See Singh (1964, p. 70) for synonymy and generic diagnosis.

Cyathidites australis Couper 1953

Plate 4 , figure 1 
Cyathidites australis Couper, New Zealand Geol. Surv. Paleontol. Bul1. 22, p. 27, pl. 2, figs. 11-12.

See Singh (1964, p. 70) for synonymy and description.

DISTRIBUTION: Jurasic and Lower Cretaceous.

Reported from various worldwide geographic

localities. Barremian to Albian, this thesis.

SIZE RANGE: 48-65 micrometers.

BOTANICAL AFFINITY: Family Cyatheaceae or Dicksoni-

aceae (Singh 1971).

Cyathidites minor Couper 1953

Plate 3 , figures 10,11

Cyathidites minor Couper, New Zealand Geol. Surv. Paleont. Bull. 22, p. 28, pl. 2, fig. 13 .

See Singh (1964, p. 71) for synonymy and description.

DISTRIBUTION: Jurassic and Cretaceous. Reported

from various worldwide geographic regions.

Jurassic to Albian, this thesis.

SIZE RANGE: 25 to 45 micrometers.

BOTANICAL AFFINITY: Family Cyatheaceae or Dicksoniaceae (Singh 1971).

Genus DELTOIDOSPORA Miner 1935 emend. Potonié 1956

Type species: Deltoidospora hallii Miner 1935.

See Singh (1964, p. 80) for synonymy and generic diagnosis. 
Deltoidospora hallii Miner 1935

$$
\text { Plate } 4 \text {, figure } 2
$$

Deltoidospora hallii Miner emend. Potonié (1956), Beih. Geol. Jahrb., Heft 23 , p. 13, pl. 1, fig. 1 . See Singh (1964, p. 80) for synonymy and description.

DISTRIBUTION: Mesozoic. Worldwide geographic distribution. Jurassic to Albian, this thesis. SIZE RANGE: 24 to 45 micrometers.

BOTANICAL AFFINITY: Family Cyatheaceae or Dicksoniaceae (Singh 1971).

Deltoidospora juncta (Kara-Murza) Singh 1964

$$
\text { Plate } 4 \text {, figures } 3,4
$$

Deltoidospora juncta (Kara-Murza) Singh, Res. Coun. Alberta, Bull. 15, p. 81, pl. 9, fig. 16 .

See Singh (1964, p. 81) for synonymy and description.

DISTRIBUTION: Upper Jurassic to Lower Cretaceous.

Reported from Alberta, Canada (Singh 1964, 1971) and from the U.S.S.R. (Kara-Murza, 1956). Barremian, this thesis.

SIZE RANGE: 24 to 37 micrometers.

BOTANICAL AFFINITY: Family Cyatheaceae or Dicksoni aceae (Singn 1971).

Deltoidospora psilostoma Rouse 1959

$$
\text { Plate } 4 \text {, figure } 5
$$


Deltoidospora psilostoma Rouse, Micropaleontol., vol. 5, p. 311, pl. 2, figs. 7-8.

See Singh (1964, p. 80) for synonymy and description. DISTRIBUTION: Upper Jurassic to Upper Cretaceous. Reported throughout western Canada. Jurassic to Albian, this thesis.

SIZE RANGE: 38 to 60 micrometers.

BOTANICAL AFFINITY: Family Cyatheaceae or Dicksoniaceae (Singh 1971).

Genus DENSOISPORITES Weyland and Krieger 1953 emend. Dettmann 1963

Type species: Densoisporites velatus Weyland and Krieger 1953.

See Dettmann (1963, p. 83) for synonymy and emended generic diagnosis.

\section{Densoisporites sp. A}

$$
\text { Plate } 4 \text {, figure } 6
$$

DESCRIPTION: Trilete; spore cingulate; amb rounded triangular; laesurae extending to junction of central body and cingulum; cingulum dense, 10 to 15 micrometers thick: scabrate sculpture on inner body.

DISTRIBUTION: Jurassic to Albian, this thesis.

SIZE RANGE: 40 to 58 micrometers.

BotaniCAL AFFinity: Family Selaginellaceae (Singh 1971). 
Genus DICTYOPHYLIDITES Couper 1958 emend. Dettmann 1963

Type species: Dictyophyllidites harrisii Couper 1958.

See Dettman (1963, p. 27) for synonymy and emended generic diagnosis.

\section{Dictyophyllidites sp. A}

$$
\text { Plate } 4 \text {, figure } 7
$$

DESCRIPTION: Trilete; laesurae extending to equatorial margin; amb triangular, sides slightly concave; laesurae surrounded by a thickened margo; exine smooth, 1-2 micrometers thick.

DISTRIBUTION: Jurassic to Barremian, this thesis. SIZE RANGE: 28 to 48 micrometers. BOTANICAL AFFINITY: Possibly Matoniaceae (Dettmann 1963).

\section{Genus DISTALANULISPORITES KIaus 1960}

Type species: Distalanulisporites punctus Klaus 1960. See Pocock (1970, p. 57) for synonymy and generic diagnosis.

\section{Distalanulisporites verrucosus Pocock 1970}

Plate 4 , figure 8

Distalanulisporites verrucosus Pocock, Palaeontographica, Band 130, Abt. B, Liefg. 3-6, p. 59, pl. 6, figs. 4 and 7 . 
DISTRIBUTION: Upper Jurassic of western Canada (Pocock, 1970). Jurassic-Hauterivian, this thesis.

SIZE RANGE: $\quad 35$ to 40 micrometers (two specimens) BOTANICAL AFFINITY: Pterophyta, Incertae Sedis.

Genus DISTALTRIANGULISPORITES Singh 1971

Type species: Distaltriangulisporites perplexus Singh 1971 . See Singh (1971, p. 88) for generic diagnosis.

\section{Distaltriangulisporites sp. A}

$$
\text { Plate } 4 \text {, figure } 9
$$

DESCRIPTION: Trilete; spore cingulate; amb triangular; laesurae reaching to the equator; thickened margo distinguishing the genus; exine smooth, 2 to 3 micrometers thick; cingulum 3 to 7 micrometers wide; margo about 5 micrometers wide.

DISTRIBLTION: Barremian to Albian, this thesis.

SIZE RANGE: 35 to 40 micrometers (three specimens).

BOTANICAL AFFINITY: Singh (1971) places this genus in the family Schizaeaceae.

Genus FORAMINISPORIS Krutzsch 1959

Type species: Foraminisporis foraminis Krutzsch 1959. See Krutzsch (1959, p. 130) for generic diagnosis. 
Foraminisporis sp. A

Plate 4, figure 10

DESCRIPTION: Trilete; circular to subtriangular amb; laesurae extending to the equator; foraminate to verrucate exine.

DISTRIBUTION: Jurassic to Barremian, this thesis. SIZE RANGE: 20 to 35 micrometers.

BOTANICAL AFFINITY: Singh (1971) places this genus in the class Hepaticae.

Genus FOVEOSPORITES Balme 1957

Type species: Foveosporites canalis Balme 1957

See Balme (1957, p. 17) for generic diagnosis.

Foveosporites subtriangularis Brenner 1963

Plate 4, figure 11

Foveosporites subtriangularis Brenner, Maryland Dept. Geol. Mines Water Resources, Bull. 27, p. 62, pl. 16, ilig. 2 . See Brenner (1963, p. 62) for description.

DISTRIBUTION: Berriasian to Albian. Reported from the Albian of Alberta, Canada (Norris 1967; Singb 1971); Barremian to Albian of Maryland, U.S.A. (Brenner 1963); Berriasian to Valanginian of Holland (Burger 1966). Barremian to Albian, this thesis. 
SIZE RANGE: 36 to 40 micrometers (several specimens).

BOTANICAL AFFINITY: Pterophyta, Incertae Sedis.

Genus GLEICHENIIDITES Delcourt and Sprumont 1955 emend. Dettmann 1963

Type species: Gleicheniidites senonicus Ross 1949. See Dettmann (1963, p. 64) for synonymy and emended generic diagnosis.

Gleicheniidites circinidites (Cookson) Dettmann 1963

Plate 4, figure 12

Gleicheniidites circinidites (Cookson) Dettmann, Proc. Roy. Soc. Victoria, vol. 77, p. 65, pl. 13, figs. 6-10. See Dettmann (1963, p. 65) for synonymy and description. DISTRIBUTION: Upper Jurassic to Lower Cretaceous. Reported from various worldwide localities. Barremian-Hauterivian, this thesis. SIZE RANGE: 20 to 33 micrometers. BOTANICAL AFFINITY: Family Gleicheniaceae (Dett$\operatorname{mann}, 1963)$.

Gleicheniidites senonicus Ross 1949 Plate 5 , figure 1 
Gleicheniidites senonicus Ross, Bull. Geol. Inst. Univ. Uppsala, vol. 34, p. 31, pl. 1, figs. 3-4.

See Singh (1964, p. 69) for synonymy and description.

DISTRIBUTION: Jurassic and Cretaceous. Worldwide geographic distribution. Jurassic to Albian, this thesis.

SIZE RANGE : 20 to 35 micrometers.

BOTANICAL AFFINITY: Family Gleicheniaceae (Singh 1971)

Genus GRANULATISPORITES Ibrahim 1933 emend. Potonié and Kemp 1954

Type species: Granulatisporites granulatus Ibrabim, Diss. Tech. Hocbschule zu Berlin (privately published), pl. 6, fig. 51 .

See Singh (1964, p. 98) for synonymy and generic diagnosis.

$$
\text { Granulatisporites sp. A }
$$

Plate 5 , figure 2

DESCRIPTION: Trilete; amb triangular, with rounded apices; laesurae extending nearly to the equator; sculpturing granulose.

DISTRIBUTION: Jurassic to Barremian, this thesis. SIZE RANGE: 25 to 35 micrometers. BOTANICAL AFFINITY: Unknown. 
Genus IMPARDECISPORA Venkatachala et al. 1969 Type species: Impardecispora apiverrucata (Couper) Venkatachala et al. 1969 .

See Venkatachala et al. (1969, p. 124) for generic diagnos is.

Impardecispora trioreticulosa (Cookson and

Dettmann) Venkatachala et al. 1969

Plate 5, figure 3

Impardecispora trioreticulosa (Cookson and Dettmann) Venkatachala et al., Palaeobotanist, vol. 17, p. 124.

See Dettmann (1963, p. 60) for description, Srivastava (1975, p. 46) for synonymy.

DISTRIBUTION: Lower Cretaceous. Reported from various worldwide locations. Barremian, this thesis.

SIZE RANGE: 75 micrometers (one specimen). BOTANICAL AFFINITY: Unknown.

REMARKS: Impardecispora is distinguished from Trilobosporites in lacking valvae in the radial regions.

Genus LAEVIGatosporites Ibrahim 1933 emend. Schopf et al. 1944 
Type species: Laevigatosporites vulgaris (Ibrahim) Ibrahim, Doctor. Diss., Tech. Hochschule zu Berlin (privately published), p. 39, pl. 2 , fig. 16.

See Singh (1964, p. 98) for synonymy and generic diagnosis.

Laevigatosporites ovatus Wilson and Webster 1946 Plate 5 , figure 4

Laevigatosporites ovatus Wilson and Webster, Am. J. Botany, vol. 33, p. 271 .

See Singh (1964, p. 99) for synonymy and description.

DISTRIBUTION: Upper Jurasic and Cretaceous.

Widespread Lower Cretaceous geographic distribu-

tion. Barremian-Albian, this thesis.

SIZE RANGE: Length, 27 to 35 micrometers; width, 22

to 28 micrometers.

BOTANICAL AFFINITY: Singh (1971) places this genus

in the Family Polypodiaceae or Dennstaedtiaceae.

Genus LEPTOLEPIDITES Couper 1953

Type species: Leptolepidites verrucatus Couper 1953.

See Couper (1953, p. 28) for generic diagnosis.

Leptolepidites sp. cf. L. verrucatus Couper 1953 Plate 5 , figure 5

Leptolepidites verrucatus Couper, N.Z. Geol. Surv. Paleonto1. Bull. 22, p. 28, p1. 2, figs. 14-15. 
See Dettmann (1963, p. 29) for description.

DISTRIBUTION: Jurassic and Cretaceous. Reported from Canada, England, Australia, and New Zealand. Jurassic to Barremian, this thesis. SIZE RANGE: 38 to 45 micrometers. BOTANICAL AFFINITY: Pterophyta, Incertae Sedis.

Genus LYCOPODIACIDITES Couper 1953 emend. Potonié 1956

Type species: Lycopodiacidites bullerensis Couper 1953. See Potonié (1956, p. 39) for emended generic diagnosis.

\section{Lycopodiacidites sp. A}

Plate 5 , figure 6

DESCRIPTION: Trilete; amb triangular to rounded triangular; laesurae almost extending to the equator; distal surface sculpture rugulate to reticulate; exine $1-2$ micrometers thick.

DISTRIBUTION: Hauterivian, this thesis.

SIZE RANGE: 40 to 43 micrometers (three specimens)

BOTANICAL AFFINITY: Singh (1971) places this genus in the family Lycopodiaceae. 
Genus LYCOPODIUMSPORITES Thiergart 1938 ex Delcourt and Sprumont 1955

Type species: Lycopodiumsporites agathoecus (Potonié) Thiergart 1938

See Singh (1964, p. 39) for synonymy and generic diagnosis.

Lycopodiumsporites austroclavatidites (Cookson) Pocock 1962

Plate 5 , figure 7

Lycopodiumsporites austroclavatidites (Cookson) Pocock, Palaeontographica, Band 111, Abt. B, p. 33, pl. 1, figs. 5-6.

See Singh (1964, p. 39) for synonymy and description.

DISTRIBUTION: Jurassic and Lower Cretaceous. Reported from various parts of the world. Jurassic to Barremian, this thesis.

SIZE RANGE: 30 to 48 micrometers.

BOTANICAL AFFINITY: Singh (1971) places this genus in the family Lycopodiaceae.

Lycopodiumsporites marginatus Singh 1964 Plate 5, figure 11

Lycopodiumsporites marginatus Singh, Res. Coun. Alberta, Bul1. 15, p. 41, p1. 1, figs. 7-10.

See Norris (1967), p. 900 for synonymy and description. 
DISTRIBUTION: Aptian-Albian. Reported from the Lower Cretaceous of Alberta, Canada (Norris 1967; Singh 1964, 1971), and of Oklahoma, U.S.A. (Hedlund and Norris 1968). Hauterivian, this thesis.

SIZE RANGE: 36 to 54 micrometers.

BOTANICAL AFFINITY: Family Lycopodiaceae (Singh 1971).

Lycopodiumsporites reticulumsporites (Rouse)

Dettmann 1963

Plate 5 , figure 8

Lycopodiumsporites reticulumsporites (Rouse) Dettmann, Proc. Roy. Soc. Victoria, vol. 77, p. 45, pl. 7, figs. 4-7. See Dettmann (1963, p. 45) for synonymy and description. DISTRIBUTION: Middle Jurassic to Albian. Reported from the Lower Cretaceous of Alberta, Canada (Norris 1964; Singh 1971); Upper Jurassic of British Columbia, Canada (Rouse 1959); Middle Jurassic of England (Lantz 1958); and the Lower Cretaceous of Australia (Dettmann, 1963). Hauterivian to Albian, this thesis.

SIZE RANGE: 30 to 45 micrometers.

BOTANICAL AFFINITY: Family Lycopodiaceae (Singh 1971). 
Genus MICRORETICULATISPORITES Knox 1950 emend. Bharadwaj 1955

Type species: Microreticulatisporites lacunosus (Ibrahim) Knox 1950 .

See Singh (1964, p. 97) for synonymy and generic diagnosis.

Microreticulatisporites diatretus Norris 1969 Microreticulatisporites diatretus Norris, Palaeont. vol. 12, pt. 4, p. 589, pl. 105, figs. 12-15.

See Norris ( 1969, p. 589) for description.

Distribution: Berriasian of England (Norris 1969).

Barremian, this thesis.

SIZE RANGE: 40 to 45 micrometers ( 2 specimens).

BOTANICAL AFFINITY: Division Pterophyta, incertae sedis.

REMARKS: Not figured because spores were folded.

Genus NEORAISTRICKIA Potonié 1956

Type species: Neoraistrickia truncata (Cookson) Potonié 1956

See Potonié (1956, p. 34) for generic diagnosis.

Neoraistrickia breviclavata (Döring) Dörhöfer 1979

Plate 5 , figure 9 
Neoraistrickia breviclavata (Döring) Dörhöfer, A.A.S.P. Contrib. ser. 5B, vol. 2, p. 111, pl. 1, fig. 28 .

See Döring ( 1965, p. 38) for description.

DISTRIBUTION: Berriasian of Europe (Dörtöfer 1979); Upper Jurassic of Germany (Döring 1965). Barremian, this thesis.

SIZE RANGE: 39 micrometers (one specimen) BOTANICAL AFFINITY: Family Selaginellaceae?

Neoraistrickia truncata (Cookson) Potonié 1956 Plate 5 , figure 10

Neoraistrickia truncata (Cookson) Potonié, Teil: Spirites, Beih. Geol. Jahrb. 23, p. 34 .

See Dettmann (1963, p. 36) for synonymy and description.

DISTRIBUTION: Jurassic and Cretaceous. Worldwide geographic occurrence. Barremian-Hauterivian, this thesis.

SIZE RANGE: 30 to 40 micrometers. BOTANICAL AFFINITY: Singh (1971) places this genus in the family Selaginellaceae.

Neoraistrickia $\mathrm{sp}$.

Plate 5 , figure 12

DESCRIPTION: Trilete; amb rounded triangular; laesurae extending $3 / 4$ to the equator; distal surface covered 
witb bacula 3 to 5 micrometers high, 2.5 to 3.5 micrometers wide; proximal surface has sparse ornamentation; exine 1 to 2 micrometers thick.

DISTRIBUTION: Barremian to Hauterivian, this thesis. SIZE RANGE: 40 to 55 micrometers. BOTANICAL AFFINITY: Family Selaginellaceae?

Genus ORNAMENTIFERA Bolkhovitina 1966

Type species: Ornamentifera echinata (Bolkhovitina) Bolkbovitina 1966 .

See Dettmann and Playford (1968, p. 77) for synonymy and description.

\section{Ornamentifera baculata Singh 1971}

Plate 6 , figure 1

Ornamentifera baculata Singh, Res. Coun. Alberta, Bull. 28, p. 100, pl. 14, figs. 4-5.

See Singh (1971, p. 100) for description.

DISTRIBUTION: Albian of Alberta, Canada (Singh, 1971). Hauterivian to Albian, this thesis. SIZE RANGE: 20 to 35 micrometers. BOTANICAL AFFINITY: Singh (1971) places this genus in the family Gleicheniaceae. 
Ornamentifera echinata (Bolkhovitina) Bolkbovitina 1966

Plate 6, figure 2

Ornamentifera echinata (Bolkbovitina) Bolkbovitina, in Nejshtadt (Ed.), The importance of palynological analysis for stratigraphic and palaeofloristic investigations, Nauka (Moscow), p. 69.

See Singh (1971, p. 98) for synonymy and description.

DISTRIBUTION: Hauterivian to Senonian. Reported from Canada, U.S.A., and U.S.S.R. Jurassic to Albian, this thesis.

SIZE RANGE: 25 to 38 micrometers.

BOTANICAL AFFINITY: Family Gleicheniaceae (Singh 1971).

Genus OSMUNDACIDITES Couper 1953

Type species: Osmundacidites wellmanii Couper 1953

See Singh (1964, p. 44) for synonymy and generic diagnosis.

Osmundacidites wellmanii Couper 1953

Plate 6, figure 3

Osmundacidites wellmanii Couper, N.Z. Geol. Surv. Paleort. Bull. 22, p. 20, pl. 1, fig. 5 .

See Dettmann (1963, p. 32) for synonymy and description. 
DISTRIBUTION: Jurassic and Cretaceous. Worldwide geograpbic occurrence. Jurassic to Albian, this thesis.

SIZE RANGE: 30 to 57 micrometers. BOTANICAL AFFINITY: Family Osmundaceae (Singh 1971).

Genus POLYCINGULATISPORITES Simoncsics and Kedves 1961 emend. Playford and Dettmann 1965

Type species: Polycingulatisporites circulus Simoncsics and Kedves 1961 .

See Playford and Dettmann (1965, p. 43) for synonymy and emended generic diagnosis.

Polycingulatisporites cf. P. reduncus (Bolkhovitina) Playford and Dettmann 1965

Plate 6, figure 4

Polycingulatisporites reduncus (Bolkhovitina) Playford and Dettmann, Senckenbergiana Letbaea, Band 46, p. 144 . See Singh (1964, p. 86) for description.

DISTRIBUTION: Middle Jurassic to Paleocene. Reported throughout various parts of the northerr hemisphere. Jurassic, this thesis.

SIZE RANGE : 25 to 30 micrometers (two specimens) BOTANICAL AFFINITY: Incertae Sedis. 
Genus ROGALSKAISPORITES Danzé-Corsin and Laveine 1963

Type species: Rogalskaisporites cicatricosus (Rogalska) Danze-Corsin and Laveine 1963.

See Singh (1971, p. 135) for synonymy and generic diagnosis.

Rogalskaisporites cicatricosus (Rogalska) DanzéCorsin and Laveine 1963

Plate 6 , figure 5

Rogalskaisporites cicatricosus (Rogalska) Danzé-Corsin and Laveine, in Briche et al., Mém. Soc. Géol. Nord, vol. $13, \mathrm{p} .80$

See Singh (1971, p. 136) for synonymy and description. DISTRIBUTION: Upper Triassic to Albian. Reported from various parts of the world. Jurassic to Albian, this thesis.

SIZE RANGE: 27 to 37 micrometers.

BOTANICAL AFFINITY: Incertae Sedis.

Genus SESTROSPORITES Dettmann 1963

Type species: Sestrosporites irregulatus (Couper) Dettmann 1963

See Dettmann (1963, p. 56) for generic diagnosis. 
Sestrosporites sp. cf. S. pseudoalveolatus (Couper) Dettmann 1963

Plate 6, figure 6

Sestrosporites pseudoalveolatus (Couper) Dettmann, Proc. Roy. Soc. Victoria, vol. 77, pt. 1, p. 66, pl. 8, figs. $11-16$.

See Dettmann (1963, p. 66) for synonymy and description.

DISTRIBUTION: Middle Jurasic to Cenomanian. Reported from various parts of the world. Hauterivian-Barremian, this thesis.

SIZE RANGE: 40 to 75 micrometers (three specimens). BOTANICAL AFFINITY: Singh (1971) places this genus in the family Lycopodiaceae.

Genus STEREISPORITES Pflug 1953

Type species: Stereisporites stereoides (Potonié and Venitz) Pflug 1953.

See Dettmann (1963, p. 25) for synonymy, Thomson and Pflug (1953, p. 53) for generic diagnosis.

Stereisporites antiquasporites (Wilson and Webster) Dettmann 1963

Plate 6 , figure 7

Stereisporites antiquasporites (Wilson and Webster) Dettmann, Proc. Roy. Soc. Victoria, vol. 77, pt. 1, p. 25 , pl. 1, figs. 20-21. 
See Dettmann (1963, p. 25) for synonymy and description.

DISTRIBUTION: Jurassic to Tertiary. Worldwide geographic occurrence. Jurassic to Barremian, this thesis.

SIZE RANGE: 20 to 38 micrometers.

BOTANICAL AFFINITY: Family Sphagnaceae (Singh $1971)$.

Genus TIGRISPORITES Klaus 1960 emend. Singh 1971

Type species: Tigrisporites halleinis Klaus 1960.

See Singh (1971, p. 139) for emended generic diagnosis.

Tigrisporites sp. cf. T. reticulatus Singh 1971 Plate 6, figure 8

Tigrisporites reticulatus Singh, Res. Coun. Alberta, Bull. 28, p. 139, p1 . 18, figs. 17-19.

See Singh (1971, p. 139) for description.

DISTRIBUTION: Albian to Cenomanian. Reported from the Albian of Alberta, Canada (Singh, 1971) and the Albian-Cenomanian of Colorado and Nebraska, U.S.A. (Pannella, 1966). Barremian, this thesis.

SIZE RANGE: 34 micrometers (two specimens). BOTANICAL AFFINITY: Incertae Sedis. 
Genus TODISPORITES Couper 1958

Type species: Todisporites major Couper 1958.

See Singh (1964, p. 45) for synonymy and generic diagnosis.

\section{Todisporites minor Couper 1958}

$$
\text { Plate 6, figure } 9
$$

Todisporites minor Couper, Palaeontographica, Band 103, Abt.

B, p. 135, pl. 16, figs. 6-8.

See Singh (1964, p. 45) for description.

Distribution: Middle Jurasic to Cenomanian. Reported from various parts of North America and England.

SIZE RANGE: 30 to 45 micrometers.

BOTANICAL AFFINITY: Family osmundaceae (Singh 1971).

Genus UNDULATISPORITES Pflug 1953

Type species: Undulatisporites microcutis Pflug 1953.

See Potonié (1956, p. 19) for generic diagnosis.

Undulatisporites fossulatus Singh 1971

Plate 6, figure 10

Undulatisporites fossulatus Singh, Res. Coun. Alberta, Bull. 28, p. 146, p1. 20 , figs. 5-8.

See Singh (1971, p. 146) for description. 
DISTRIBUTION: Singh (1971) reported this species from the Albian of Alberta, Canada. Barremian and Albian, this thesis.

SIZE RANGE: 18 to 30 micrometers (two specimens). BOTANICAL AFFINITY: Incertae Sedis.

\section{Undulatisporites sp. A}

$$
\text { Plate 6, figure } 11
$$

DESCRIPTION: Trilete; laesurae extending to equator; commissures raised, undulate; amb rounded triangular: exine 1-2 micrometers thick, psilate.

SIZE RANGE: 22 to 38 micrometers.

BOTANICAL AFFINITY: Incertae Sedis.

DISTRIBUTION: Aptian to Hauterivian, this thesis.

REMARKS: Not figured because of poor preservation.

Genus VERRUCOSISPORITES Ibrahim 1933 emend. Potonié and Kremp 1954

Type species: Verrucosisporites verrucosus Ibrahim 1933 emend. Potonif and Kremp, 1955.

See Singh (1964, p. 95) for synonymy and generic diagnosis.

Verrucosisporites asymmetricus (Cookson and Dettmann) Pocock 1962

Plate 7 , figure 1 
Verrucosisporites asymmetricus (Cookson and Dettmann) Pocock, Palaeontographica, Band 111, Abt. B, p. 56, pl. 8, figs. $124-126$.

See Singh ( 1964, p. 95) for synonymy and description. DISTRIBUTION: Aptian to Albian of Alberta, Canada (Pocock 1962; Singh 1964) and of Australia (Cookson and Dettmann 1958). Jurassic to Albian, this thesis.

SIZE RANGE: 30 to 40 micrometers. BOTANICAL AFFINITY: Incertae Sedis.

\section{Verrucosisporites sp. A}

Plate 6, figure 12

DESCRIPTION: Trilete; laesurae faint; amb triangular to rounded triangular; both proximal and distal surfaces ornamented by verrucae 2 to 4 micrometers in diameter; verrucae densely packed.

SIZE RANGE: 20 to 40 micrometers.

BOTANICAL AFFINITY: Incertae Sedis. 
Gymnospermic Pollen

Genus ABIETINeaepollenites Potonié 1951 ex Delcourt and Sprumont 1955

Type species: Abietineaepollenites microalatus (Potoniê) Delcourt and Sprumont 1955.

See Burger (1966, p. 258) for generic diagnosis.

Abietineaepollenites microreticulatus Groot and

$$
\begin{aligned}
& \text { Penny } 1960 \\
& \text { Plate } 7 \text {, figure } 3
\end{aligned}
$$

Abietineaepolienites microreticulatus Groot and Penny, Micropaleont., vol. 6 , no. 2, p. 231 , pl. 2 , figs. $1 \& 3$.

See Burger (1966, p. 258) for description.

DISTRIBUTION: Upper Jurassic to Cenomanian. Reported from the Lower Cretaceous and Cenomanian of Maryland and Delaware, U.S.A. (Groot and Penny 1960); and from the Upper Jurassic to Valanginian of Holland (Burger 1966). Jurassic to Barremian, this thesis.

SIZE RANGE: 50 to 65 micrometers, total length, height of central body 48 to 55 micrometers. BOTANICAL AFFINITY: Coniferophyta. 
Genus ALISPORITES Daugherty 1941 restr. Potonié and Kremp 1956

Type species: Alisporites opii Daugherty 1941.

See Singh (1964, p. 107) for synonymy and generic diagnosis.

\section{Alisporites bilateralis Rouse 1959}

Plate 7 , figure 1

Alisporites bilateralis Rouse, Micropaleont., vol. 5, p. 316, pl. 1, figs. 10-11.

See Singh (1964, p. 109) for description, Singh (1971, p. 169) for synonymy.

DISTRIBUTION: Upper Jurasic to Cenomanian. Widespread geographic occurrence throughout N. America. Jurassic to Albian, this thesis.

SIZE RANGE: Total length of grain 45 to 80 micrometers, height of central body 38 to 55 micrometers.

BOTANICAL AFFINITY: Order Coniferales.

Alisporites grandis (Cookson) Dettmann 1963

Plate 7 , figure 2

Alisporites grandis (Cookson) Dettmann, Proc. Roy. Soc. Victoria, vol. 77 , pt. 1, p. 102 , pl. 25 , figs. 1-4.

DISTRIBUTION: Upper Jurassic and Lower Cretaceous. Reported from various localities in $\mathrm{N}$. America and Australia. 
SIZE RANGE: Total length of grain 85 to 130 micrometers, width of grain 65 to 95 micrometers. BOTANICAL AFFINITY: Order Coniferales.

Alisporites microsaccus (Couper) Pocock 1962

Alisporites microsaccus (Couper) Pocock, Palaeontographica, Band 111, Abt. B, p. 61, pl. 9, figs. 138-139.

See Singh (1964, p. 108) for synonymy and description.

DISTRIBUTION: Upper Jurassic to Lower Cretaceous. Reported from western Canada (Pocock 1962; Singh 1964) and from the Canadian Arctic (McGregor 1965). Hauterivian-Barremian, this thesis.

SIZE RANGE: Total length of grain 50 to 75 micrometers, beight of central body 40 to 55 micrometers (two specimens).

BOTANICAL AFFINITY: Order Coniferales.

REMARKS: Not figured because of poor preservation.

\section{Alisporites sp. A \\ Plate 7 , figure 5}

DESCRIPTION: See generic diagnosis in Singh (1964, p. 108). Pollen grain circular to subcircular.

DISTRIBUTION: Barremian, this thesis.

SIZE RANGE: Total length of grain equal to total width, 55 micrometers, central body 35 micrometers across. BOTANICAL AFFINITY: Order Coniferales. 
Genus ARAUCARIACITES Cookson 1947 ex Couper 1953 Type species: Araucariacites australis Cookson 1947 . See Potonié (1958, p. 81) for generic diagnosis.

\section{Araucariacites australis Cookson 1947}

Plate 7 , figure 6

Araucariacites australis Cookson, B.A.N.Z. Antarct. Res. Exped. (1929-1931) Rept. A2 (Geol.), p. 8, p. 130, p1. 13, figs. 1-4.

See Couper (1958, p. 151) for synonymy and description. DISTRIBUTION: Jurassic and Lower Cretaceous. Worldwide geographic occurrence. Barremian to Albian, this thesis. SIZE RANGE: 50 to 65 micrometers. BOTANICAL AFFINITY: Family Araucariaceae.

\section{Genus CEDRIPITES Wodehouse 1933}

Type species: Cedripites eocenicus Wodehouse 1933. See Singh (1964, p. 111) for synonymy and description.

Cedripites sp. cf. C. canadensis Pocock 1962 Plate 7 , figure 7

Cedripites canadensis Pocock, Palaeontographica, Band 111, Abt. B, p. 63, pl. 10, figs. 149-150. See Singh (1964, p. 112) for synonymy and description. 
DISTRIBUTION: Barremian to Albian. Reported from the Lower Cretaceous of Alberta, Canada (Pocock 1962; Singh 1964, 1971; Norris 1967). Jurassic to Albian, this thesis.

SIZE RANGE: Total length of grain, 60 to 85 micrometers; breadth of grain, 40 to 55 micrometers. BOTANICAL AFFINITY: Order Coniferales.

Genus CEREBROPOLLENITES Nilss on 1958

Type species: Cerebropollenites mesozoicus (Couper) Nilsson 1958 .

See Nilsson (1958, p. 72) for generic diagnosis.

Cerebropollenites mesozoicus (Couper) Nilsson 1958

Plate 7 , figure 4

Cerebropollenites mesozoicus (Couper) Nilsson, Lunds Universitets Arsskrift, N.F., Avd. 2, Band 54, p. 72, p1.6, figs. $10-12$.

See Burger (1966, p. 261) for description, Singh (1971, p. 172) for synonymy.

DISTRIBUTION: Jurassic and Cretaceous. Widespread geographically throughout $N$. America and Europe. Jurassic to Albian, this thesis. SIZE RANGE: 35 to $55 \mathrm{micrometers.}$ BOTANICAL AFFINITY: Gymnospermous. 
Genus CLASSOPOLLIS Pflug 1953 emend. Pocock and Jansonius 1961

Type species: Classopollis classoides Pflug 1953.

See Singh (1964, p. 124) for synonymy and generic diagnosis.

Classopollis classoides Pflug 1953 emend. Pocock

$$
\begin{aligned}
& \text { and Jansonius } 1961 \\
& \text { Plate } 7 \text {, figure } 8
\end{aligned}
$$

Classopollis classoides Pflug, Palaeontographica, Band 95 , Abt. B, p. 91, pl. 16, figs. 29-31.

DISTRIBUTION: Jurassic and Cretaceous. Widespread geographically throughout various parts of the world. Barremian-Hauterivian, this thesis.

SIZE RANGE: 20 to 35 micrometers.

BOTANICAL AFFINITY: Coniferophyta, Incertae Sedis.

Classopollis torosus (Reissinger) Balme 1957

Plate 7 , figure 9

Classopollis torosus Balme 1957 , C.S.I.R.O. Aust., Coal Res. Sect., T.C., 25, p. 37, pl. 11, figs. 114-119.

See Balme (1957, p. 37) for description, Norris (1967, p. 110) for synonymy .

DISTRIBUTION: Lipper Triassic to Lower Cretaceous. Worldwide geographic distribution. BarremianHauterivian, this thesis.

SIZE RANGE: $22-30$ micrometers. 
BOTANICAL AFFINITY: Coniferophyta, Incertae Sedis.

GsnuS EQUISETOSPORITES Daugherty 1941 emend. Singh 1964

Type species: Equisetosporites chinleana Daugherty 1941. See Singh (1964, p. 129) for synonymy and emended generic diagnosis.

Equisetosporites virginiaensis (Brenner) Singh 1971

Plate 7 , figure 11; Plate 8 , figure 1

Equisetosporites virginiaensis (Brenner) Singh 1971, Res. Coun. Alberta, Bull. 28, p. 180, pl. 26, fig. 14. See Brenner (1963, p. 90) for description.

DISTRIBUTION: Barremian to Albian. Reported from the Albian of Alberta, Canada (Singh 1971) and the Barremiar of Maryland, U.S.A. (Brenner 1963). Hauterivian, this thesis.

SIZE RANGE: Length, 20 to 40 micrometers; width, 14 to 25 micrometers.

BOTANICAL AFFINITY: Singh (1971) places this genus in the family Ephedraceae. 
Genus EUCOMMIIDITES Erdtman 1948 emend. Hughes 1961

Type species: Eucommiidites troedssonii Erdtman 1948. See Singh (1964, p. 127) for synonymy and generic diagnosis.

Eucommiidites minor Groot and Penny 1960

Plate 8 , figure 2

Eucommiidites minor Groot and Penny, Micropaleont., vol. 6, no. 2, p. 234 .

See Groot and Penny (1960, p. 234) for description.

DISTRIBUTION: Upper Jurassic to Albian. Reported

from various localities of $N$. America and

Europe. Barremian-Hauterivian, this thesis.

SIZE RANGE: 26 to 37 micrometers.

BOTANICAL AFFINITY: Coniferophyta, Incertae Sedis.

Genus EXESIPOLLENITES BaIme 1957

Type species: Exesipollenites tumulus Balme 1957.

See Singh (1964, p. 126) for synonymy and generic diagnosis.

Exesipollenites tumulus Balme 1957

Plate 8 , figure 3

Exesipollenites tumulus Balme, C.S.I.R.O., Aust., T.C. 25, p. 39, pl. 11, figs. 123-125.

See Singh (1964, p. 126) for synonymy and description. 
DISTRIBUTION: Lower Jurassic to Middle Albian. Reported from western Canada (Pocock 1970; Singh 1964, 1971); Lower Cretaceous of Maryland, U.S.A. (Brenner 1963); Lower Jurasssic of western Australia (Balme 1957). BarremianHauterivian, this thesis.

SIZE RANGE: 13 to 30 micrometers.

BOTANICAL AFFINITY: Coniferophyta, Incertae Sedis.

Genus GINKGOCYCADOPHYTUS Samoilovitch 1953

Type species: Ginkgocycadophytus caperatus (Luber) Samoilovitch 1953.

See Potonié (1958, p. 93) for generic diagnosis.

Ginkgocycadophytus nitidus (Balme) de Jersey 1962

Plate 7 , figure 10

Ginkgocycadophytus nitidus (Balme) de Jersey, Qd. Dept.

Mines Publ. 307, p. 12 , pl. 5, figs. 1-3.

See Dettmann (1963, p. 104) for synonymy and description.

DISTRIBUTION: Triassic to Cretaceous. Geographically widespread in various parts of the world. Jurassic to Albian, this thesis.

SIZE RANGE: Length, 30 to 60 micrometers; breadth, 13 to 40 micrometers. 
BOTANICAL AFFINITY: Order Cycadales, Bennettitales, Ginkgoales (Singh 1971).

Genus GNETACEAEPOLLENITES Thiergart 1938 emend. Srivastava 1968

Type species: Gnetaceaepollenites ellipticus Thiergart, Jb. Preuss. Geol. Landesanstalt, vol. 58, p. 307, pl. 24, fig. 9 .

See Srivastava (1968, p. 213) for emended generic diagnosis.

\section{Gnetaceaepollenites sp. A \\ Plate 8 , figures 4,5}

DESCRIPTION: Polyplicate, acolpate pollen grains; outline fusiform; cicatricose sculpture; ribs 3 to 4 micrometers wide, coalescing at the longitudinal ends.

DISTRIBUTION: Hauterivian, this thesis.

SIZE RANGE: Length, 44 to 50 micrometers; width, 27 to 33 micrometers (two specimens).

BOTANICAL AFFINITY: Azéma and Boltenhagen (1974) place this genus in the order Welwitschiales or Ephedrales.

Genus INAPERTUROPOLLENITES Thomson and Pflug 1953 emend. Potonié 1958

Type species: Inaperturopollenites dubius (Potonié and Venitz) Thoms on and Pflug 1953. See Potonié (1958, p. 77) for emended generic diagnosis. 
Inaperturopollenites dubius (Potonié and Venitz Thoms on and Pflug 1953

Plate 8 , figure 6

Inaperturopollenites dubius (Potonié and Venitz) Thomson and Pflug, Palaeontographica, Band 94, Abt. B, p. 65, pl. 4, fig. $89, \mathrm{pl} .5$, figs. 1-13.

See Thomson and Pflug (1953, p. 65) for description.

DISTRIBUTION: Jurassic, Cretaceous, and Tertiary.

Worldwide geographic distribution. Jurassic to Albian, this thesis.

SIZE RANGE: 40 to 50 micrometers.

BOTANICAL AFFINITY: Incertae Sedis. Brenner (1963) suggests possible relationship to Taxodiaceae or Cuppressaceae.

Inaperturopollenites turbatus Balme 1957

Plate 8 , figure 7

Inaperturopollenites turbatus Balme, C.S.I.R.O., Aust., Coal. Res. Sect., T.C. 25, p. 31, pl. 7, figs. 85-86, pl. 8, fig. 87 .

See Pocock (1970, p. 75) for synonymy and description.

DISTRIBUTION: Jurasic to Lower Cretaceous. Widespread geographic distribution in Australia, Europe, and Canada. Jurassic to Albian, this thesis. 
SIZE RANGE: 50 to 75 micrometers.

BOTANICAL AFFINITY: Incertae Sedis, but probably gymnospermous.

\section{Genus PARVISACCITES Couper 1958}

Type species: Parvisaccites radiatus Couper 1958.

See Singh (1964, p. 112) for synonymy and generic diagnosis.

Parvisaccites radiatus Couper 1958

\section{Plate 8 , figure 9}

Parvisaccites radiatus Couper, Palaeontographica, Band 103, Abt. B, p. 154, pl. 29, figs. 5-8, pl. 30, figs. 1-2. See Singh (1964, p. 112) for synonymy and description.

DISTRIBUTION: Upper Jurassic to Cenomanian. Reported from various localities across North America and Europe. Hauterivian to Albian, this thesis.

SIZE RANGE: Total length of grain, 60 to 75 micrometers; breadth of grain, 40 to 55 micrometers. BOTANICAL AFFINITY: Order Coniferales.

\section{Genus PERINOPOLLENITES Couper 1958}

Type species: Perinopollenites elatoides Couper 1958. See Singh (1964, p. 107) for synonymy and generic diagnosis. 


\section{Perinopollenites elatoides Couper 1958}

$$
\text { Plate } 8 \text {, figure } 10
$$

Perinopollenites elatoides Couper, Palaeontographica, Band 103, Abt. B, p. 152, pl. 27, figs. 9-11.

DISTRIBUTION: Jurassic to Cenomanian. Reported from various parts of the world. Jurassic to Barremian, this thesis.

SIZE RANGE: 30 to 65 micrometers.

BOTANICAL AFFINITY: Family Taxodiaceae (Singh 1971).

Genus PHYLLOCLADIDITES Cookson 1947 ex Couper 1953

Type species: Phyllocladidites mawsonii Cookson 1947.

See Singh (1964, p. 113) for synonymy and generic diagnosis.

Phyllocladidites sp. A

Plate 8 , figure 8

DESCRIPTION: Bisaccate; equatorial outline of the body oval; exine granulose; bladders narrow, elongated, distally pendent, attached to the central body by their entire length; distal furrow present between the bladders.

DISTRIBUTION: Hauterivian-Barremian, this thesis. 
SIZE RANGE: Total length of grain, 60 to 70 micrometers; widtb of grain 75 to 85 micrometers; bladder widtb, about 55 micrometers.

BOTANICAL AFFINITY: Order Coniferales.

Genus PODOCARPIDITES Cookson 1947 ex Couper 1953 Type species: $\quad$ Podocarpidites ellipticus Cookson 1947. See Singh (1964, p. 115) for synonymy and generic diagnosis.

\section{Podocarpidites biformis Rouse 1957}

\section{Plate 8 , figure 11}

Podocarpidites biformis Rouse, Can. J. Bot., vol. 35, no. 3, p. 367, pl. 2, fig. 13 .

See Rouse ( 1957 , p. 367) for description.

DISTRIBUTION: Upper Jurassic to Campanian. Reported from western Canada (Rouse 1957, 1959; Singh 1971); Canadian Arctic (McGregor 1965); and Wyoming, U.S.A. (Davis 1963). Hauterivian to Albian, this thesis.

SIZE RANGE: Total length of grain, 90 to 110 micrometers; width of central body, 40 to 70 micrometers; width of bladders, 55 to 65 micrometers.

BOTANICAL AFFINITY: Family Podocarpaceae (Singh 1971). 


\section{Podocarpidites granulatus Singh 1971}

Plate 8 , figure 12

Podocarpidites granulatus Singh, Res. Coun. Alberta, Bull. 28, p. 164, pl. 23, figs. 6-9.

See Singh (1971, p. 164) for description.

DISTRIBUTION: Albian of Alberta, Canada (Singh 1971). Jurassic to Albian, this thesis. SIZE RANGE: Total length of grain, 45 to $65 \mathrm{microm-}$ eters; breadth of grain, 30 to 40 micrometers. BOTANICAL AFFINITY: Family Podocarpaceae.

REMARKS: I have extended the range of this species because I think it has a greater range than Singh originally recognized.

Podocarpidites multesimus (Bolkhovitina) Pocock 1962

Plate 9, figure 1

Podocarpidites multesimus (Bolkhovitina) Pocock, Palaeontographica, Band 111, Abt. B, p. 67, pls. 10-11, figs. $161-163$.

See Singh (1964, p. 116) for synonymy and description. DISTRIBUTION: Jurassic and Cretaceous. Reported from various parts of Canada, U.S.S.R., and Australia. Hauterivian to Barremian, this thesis. 
SIZE RANGE: Total length of grain, 55 to 80 micrometers; width of grain, 37 to 48 micrometers. BOTANICAL AFFINITY: Family Podocarpaceae (Singh 1971)

\section{Podocarpidites sp. A}

$$
\text { Plate } 9 \text {, figure } 2
$$

DESCRIPTION: Bisaccate; exine granulose; central body round to oval; bladders distally pendent, wider than the central body and thinner walled; bladders reticulate (to granulose).

DISTRIBUTION: Hauterivian to Albian, this thesis.

SIZE RANGE: Total length of grain, 50 to 70 micrometers; breadth of central body, 30 to 35 micrometers; breadth of bladders, 32 to 40 micrometers.

BOTANICAL AFFINITY: Family Podocarpaceae (Singh 1971).

Genus RUGUBIVESICULITIES Pierce 1961

Type species: Rugubivesiculites convolutus Pierce 1961.

See Potonié (1966, p. 126) for generic diagnosis in.

Rugubivesiculities sp. A

Plate 9, figure 3

DESCRIPTION: Bisaccate; central body exine rugulate to verrucose; bladders slightly larger than the central body, exine granulose. 
DISTRIBUTION: Barremian, this thesis.

SIZE RANGE: Total length of grain, 45 to 55 micrometers; breadth of central body, 35 to 40 micrometers; breadth of bladders, 37 to 42 micrometers.

BOTANICAL AFFINITY: Order Coniferales.

Genus VITREISPORITES Leschik 1955 emend. Jansonius 1962

Type species: Vitreisporites signatus Leschik 1955. See Singh (1964, p. 102) for generic diagnosis.

Vitreisporites pallidus (Reissinger) Nilsson 1958

Plate 9 , figure 4

Vitreisporites pallidus (Reissinger) Nilsson, Publ. Inst. Mineral., Paleont. Quaternary Geol., Univ. Lund, no. 53, pp. $77-78$.

See Singh (1964, p. 102) for synonymy and description.

DISTRIBUTION: Jurassic and Cretaceous. Worldwide geographic occurrence. Jurassic to Albian, this thesis.

SIZE RANGE: Total length of grain, 20 to 40 micrometers; breadth of grain, 15 to 25 micrometers. BOTANICAL AFFINITY: Family Caytoniaceae (Singh 1971) 
Angiospermic Pollen

Genus CLAVATIPOLLENITES Couper 1958

Type species: Clavatipollenites hughesii Couper 1958.

See Couper (1958, p. 159) for generic diagnosis.

Clavatipollenites cf. C. couperi Pocock 1962

Plate 9 , figure 5

Clavatipollenites couperi Pocock, Palaeontographica, Bard 111, Abt. B, p. 74, pl. 12, figs. 190-192, pl. 13, fig. 193 .

See Couper (1958, p. 74) for description.

DISTRIBUTION: Upper Jurassic of western Canada (Pocock, 1962). Barremian-Hauterivian this thesis.

SIZE RANGE: Length 30 to 35 micrometers, width 15 to $28 \mathrm{micrometers.}$

BOTANICAL AFFINITY: Subclass Monocotyledoneae, Incertae Sedis, according to Singh (1971).

Genus LILIACIDITES Couper 1953

Type species: Liliacidites kaitangataensis Couper 1953. See Couper (1953, p. 56) for generic diagnosis. 


\section{Liliacidites $\mathrm{sp} . \mathrm{A}$}

\section{Plate 9 , figures 6,7}

DESCRIPTION: Monosulcate; sulcus faint; amb elongate oval to oval; proximal and distal surfaces having reticulate sculpture; lumina 2 to 4 micrometers in diameter, elongate to equidimensional.

DISTRIBUTION: Barremian to Albian, this thesis.

SIZE RANGE: 20 to 30 micrometers.

BOTANICAL AFFINITY: Angiospermae, Incertae Sedis (Singh 1971). 
Plate 1

All figures $1000 x$ unless otherwise specified.

1. Acanthotriletes levidensis, p. 30 .

2. Acanthotriletes levidensis, p. 30.

3. Acanthotriletes varispinosus, p. 31 .

4. Aequitriradites sp. cf. A. variabilis (500X), p. 32 .

5. Baculatisporites comaumensis, p. 32 .

6. Baculatisporites comaumensis, p. 32.

7. Biretisporites potoniaei, p. 33.

8. Biretisporites sp. A, p. 34 .

9. Camarozonosporites sp. cf. C. insignis (500X), p. 35 .

10. Calamospora mesozoica, p. 34.

11. Camarozosporites sp. cf. C. insignis, p. 35 . 

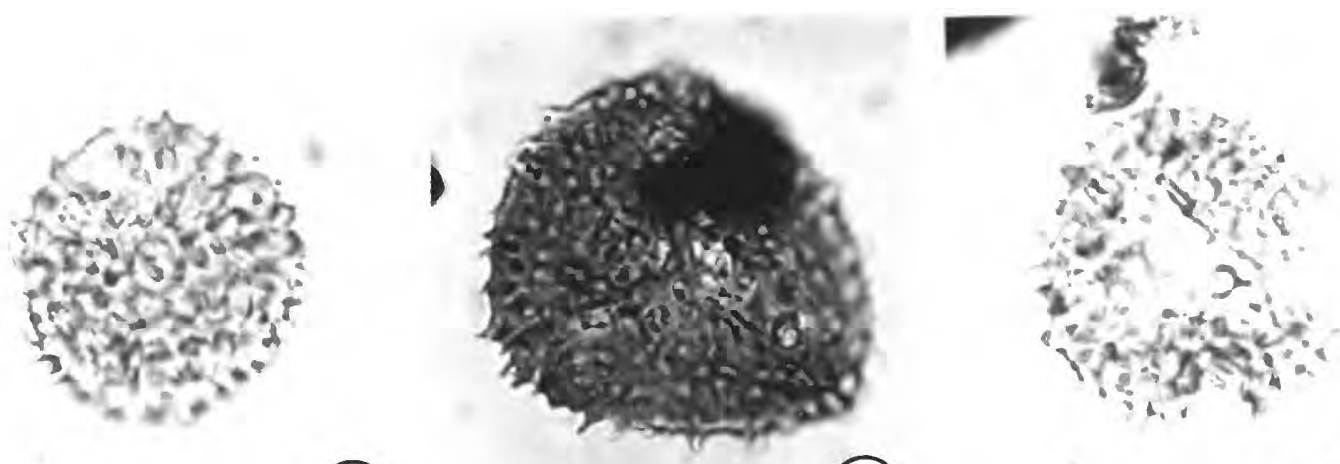

(1)
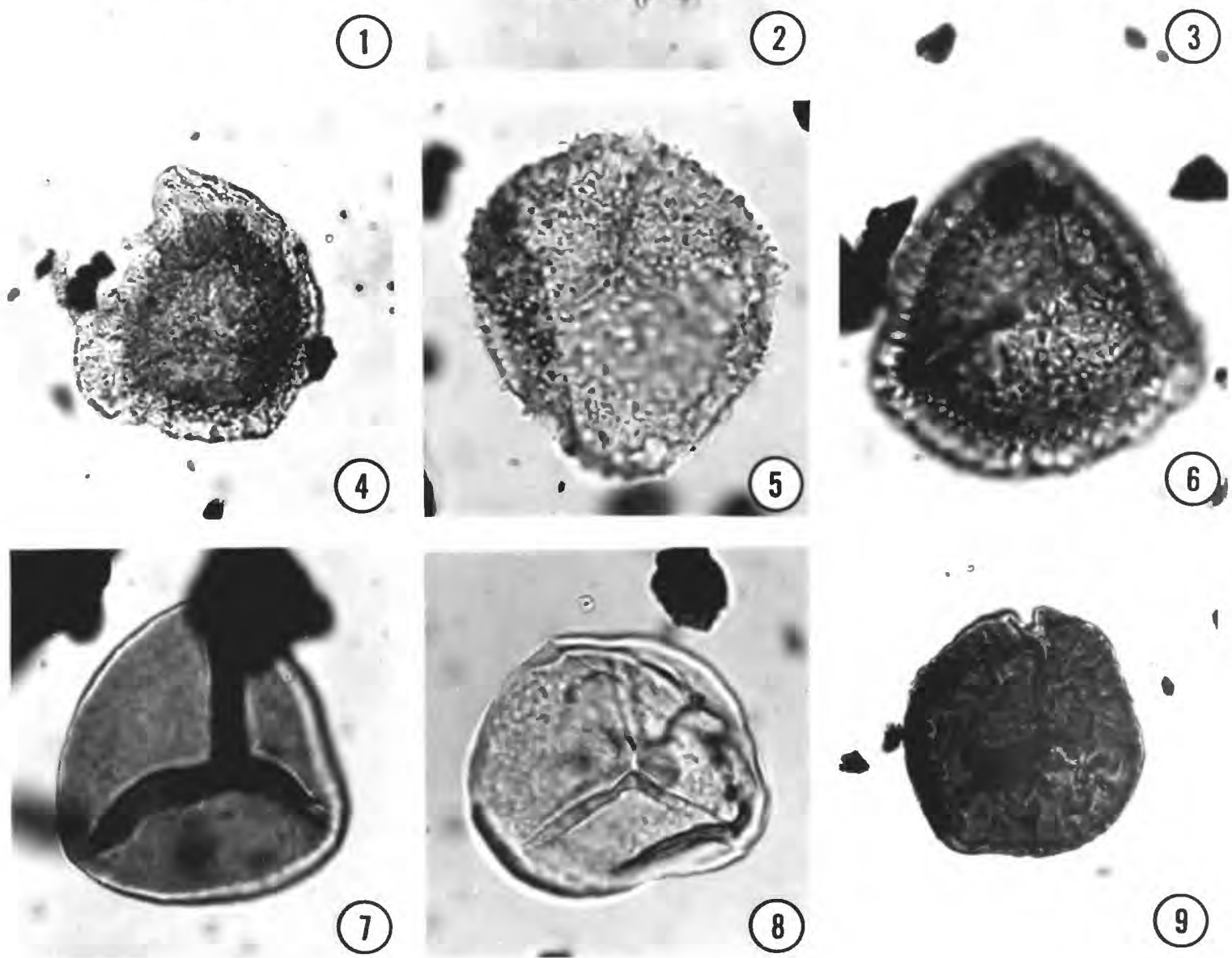

(7)

(B)

(9)
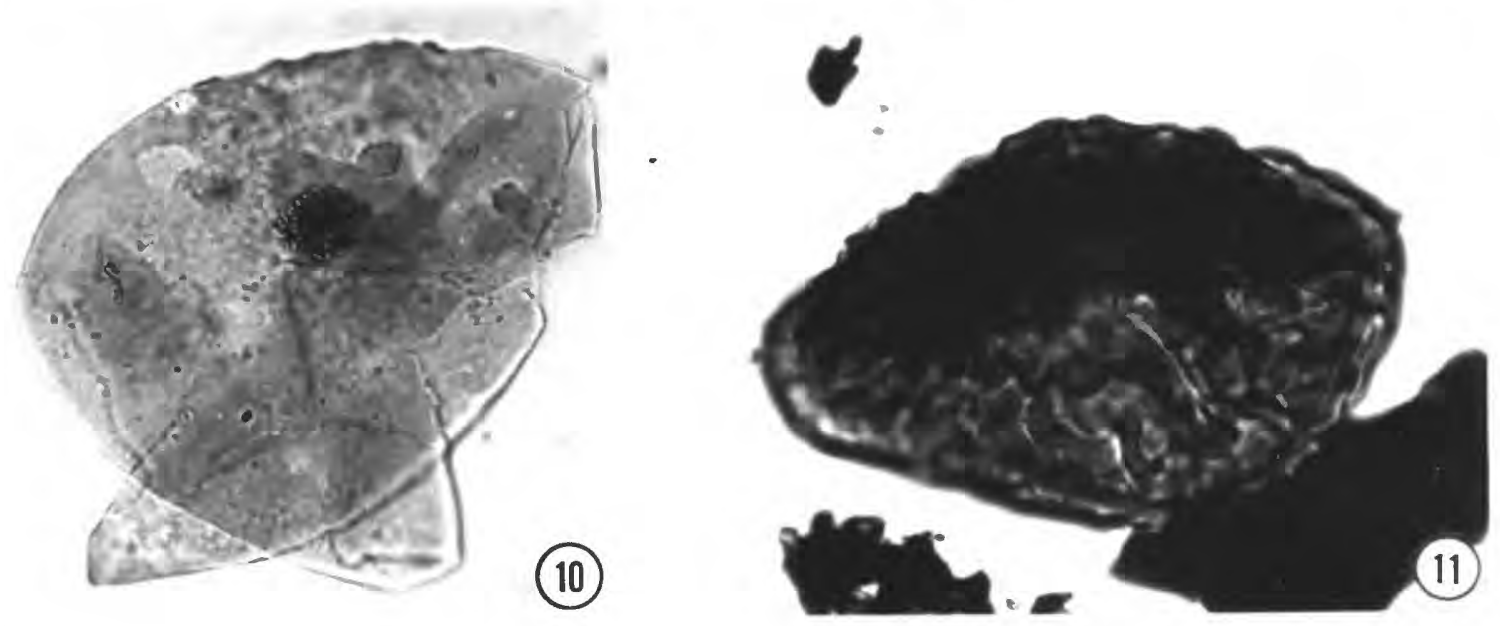


\section{Plate 2}

Al1 figures 1000X.

1. Ceratosporites sp. A, p. 36 .

2. Cicatricosisporites annulatus, p. 37 .

3. Cicatricosisporites annulatus, p. 37 .

4. Cicatricosisporites augustus, p. 38 .

5. Cicatricosisporites augustus, p. 38 .

6. Cicatricosisporites australiensis, p. 38 .

7. Cicatricosisporites hallei, p. 39.

8. Cicatricosisporites pseudotripartitus, p. 39 .

9. Cicatricosisporites sp. A, p. 40 .

10. Cingutriletes clavus, p. 41 .

11. Cingutriletes clavus, p. 41 .

12. Cingutriletes sp. A, p. 41 . 


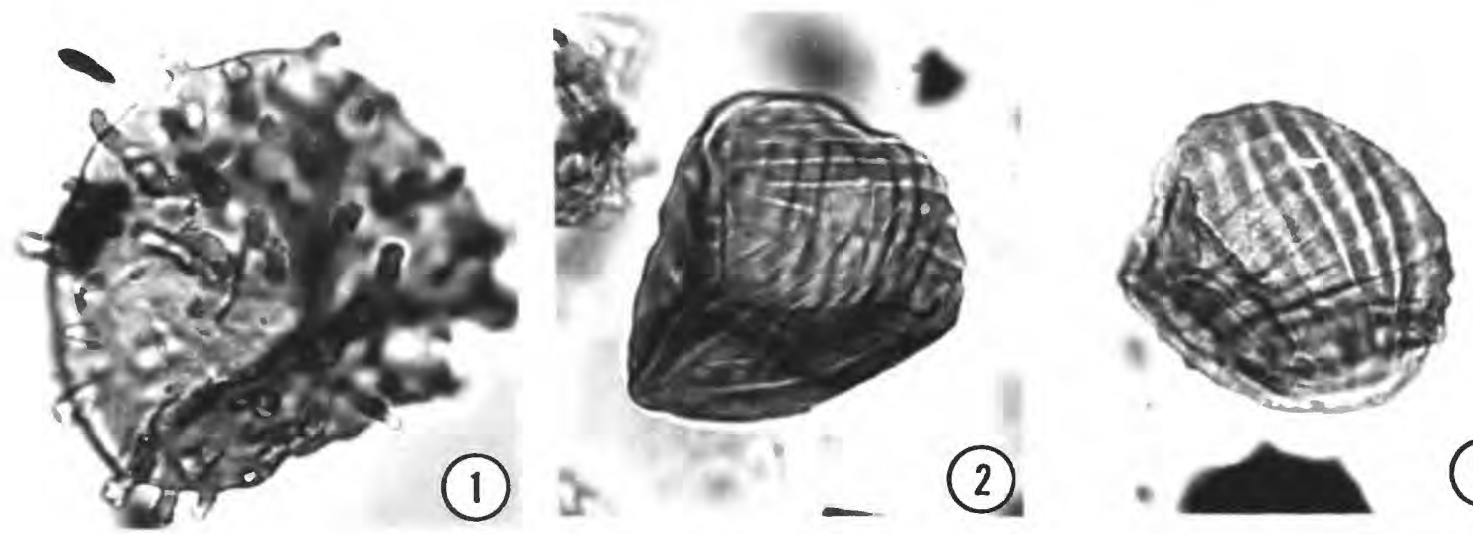

(3)
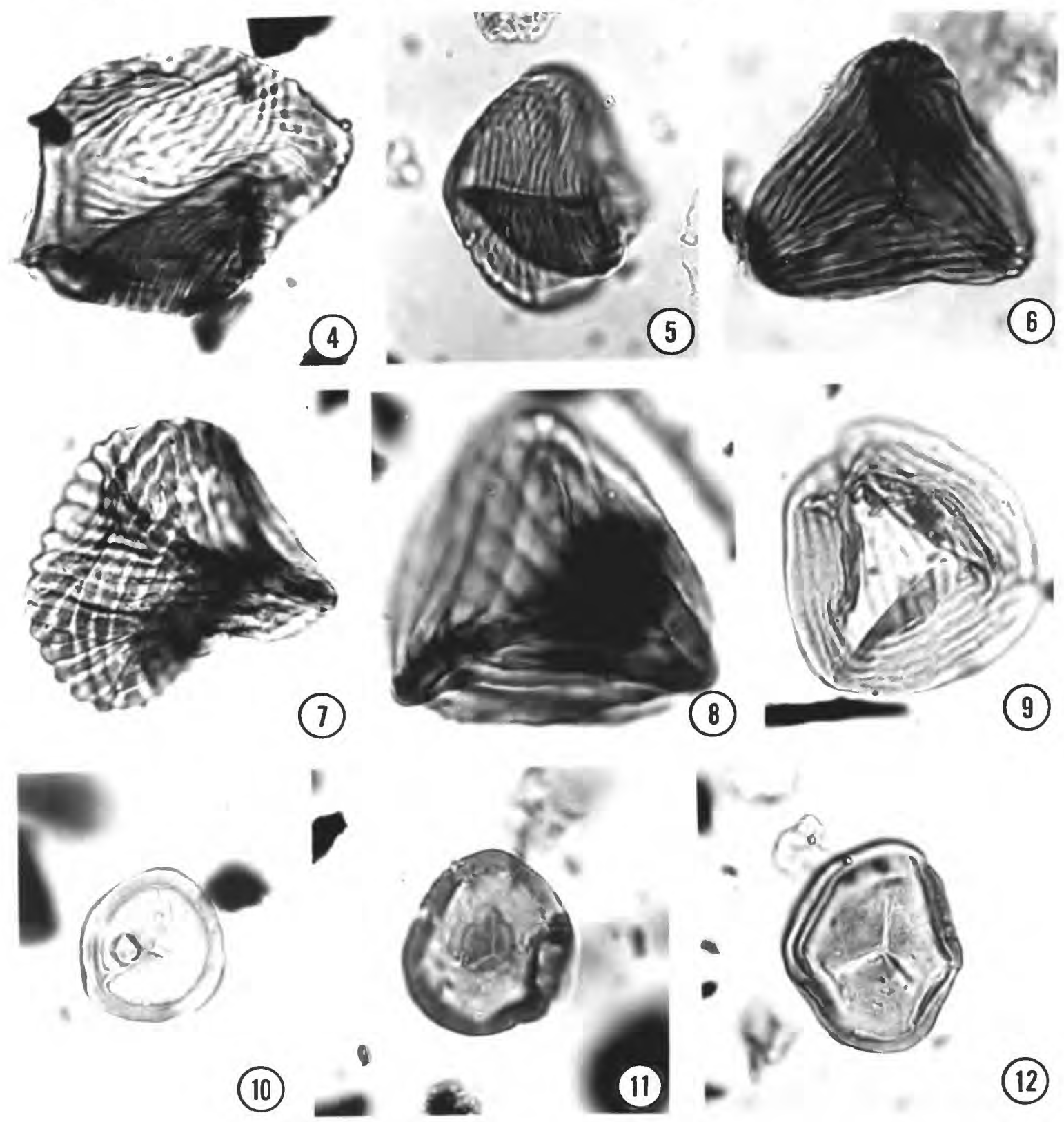
Plate 3

All figures 1000X unless otherwise specified.

1. Concavisporites sp. A, p. 42 .

2. Concavissimisporites minor (500X), p. 42 .

3. Concavissimisporites punctatus (500X), p. 43 .

4. Concavissimisporites minor, p. 42 .

5. Concavissimisporites punctatus, p. 43 .

6. Concavissimisporites variverrucatus, p. 43 .

7. Converrucosisporites $\mathrm{sp.} \mathrm{cf.} \mathrm{C.} \mathrm{exquisitus} \mathrm{(500X),}$

8. Couperisporites complexus ( $500 x)$, p. 45 .

9. Crybelosporites pannuceus, p. 46.

10. Cyathidites minor, p. 47 .

11. Cyathidites minor, p. 47 . 

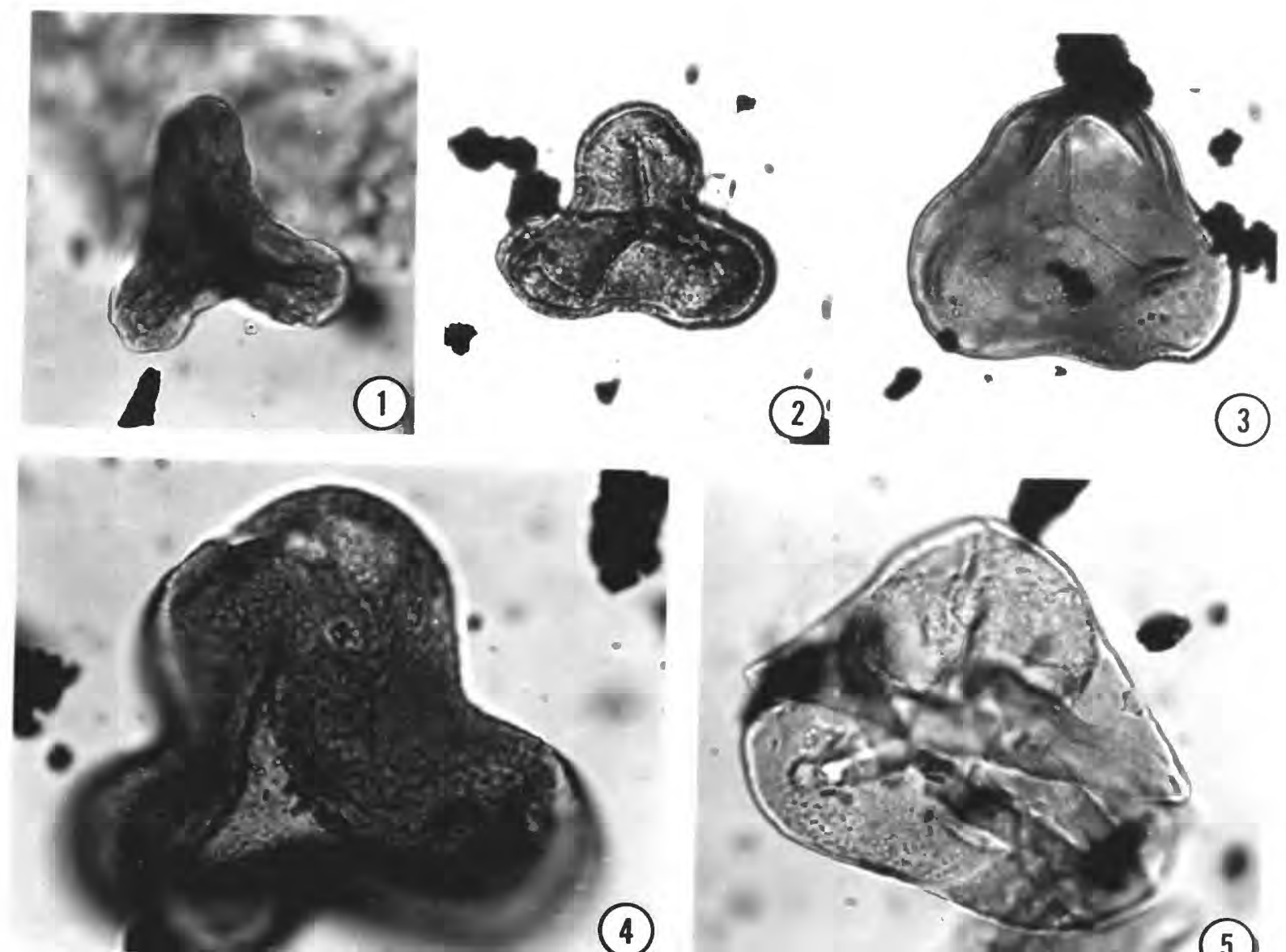

(4)
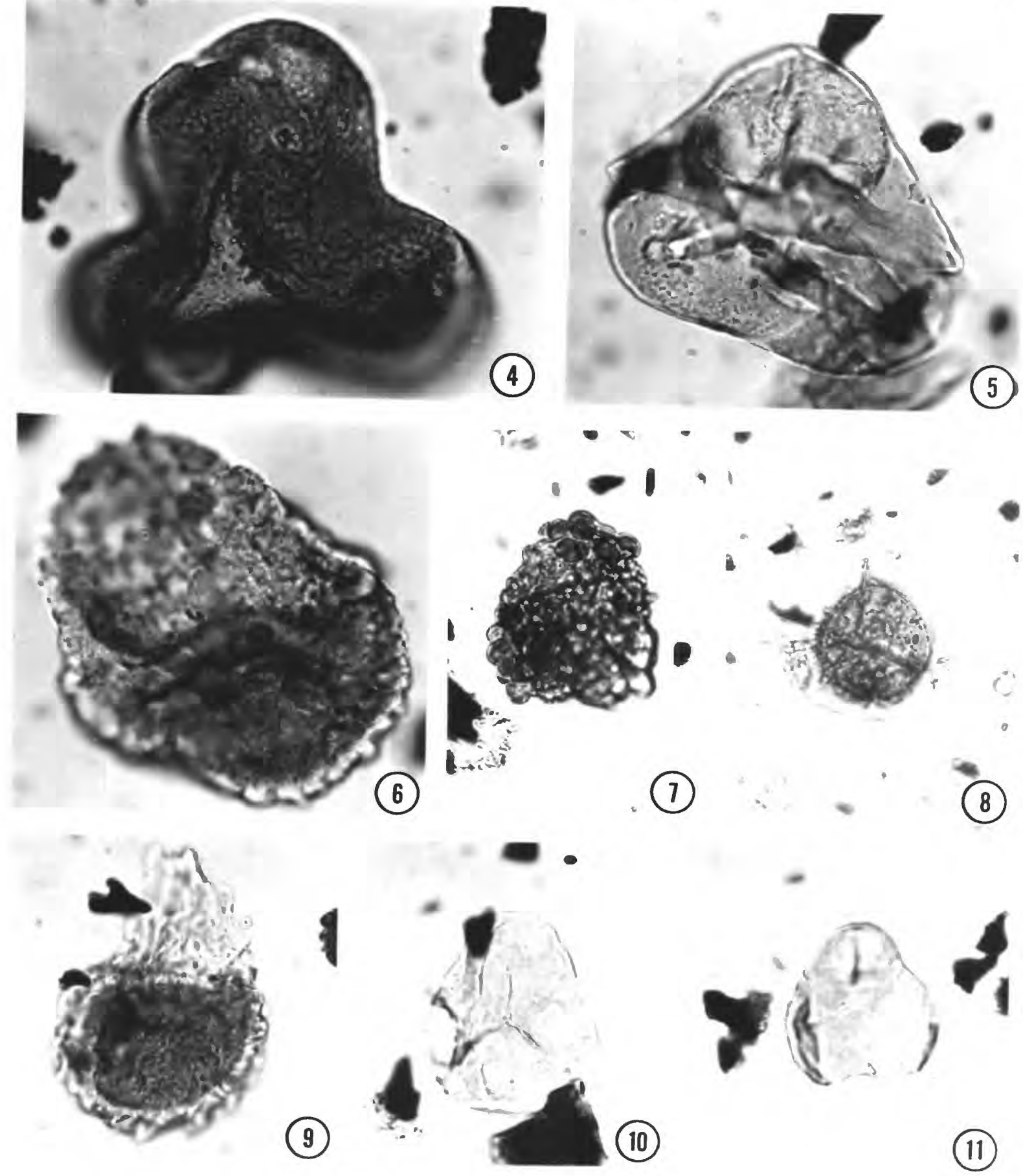

(1) $\because$ (8)
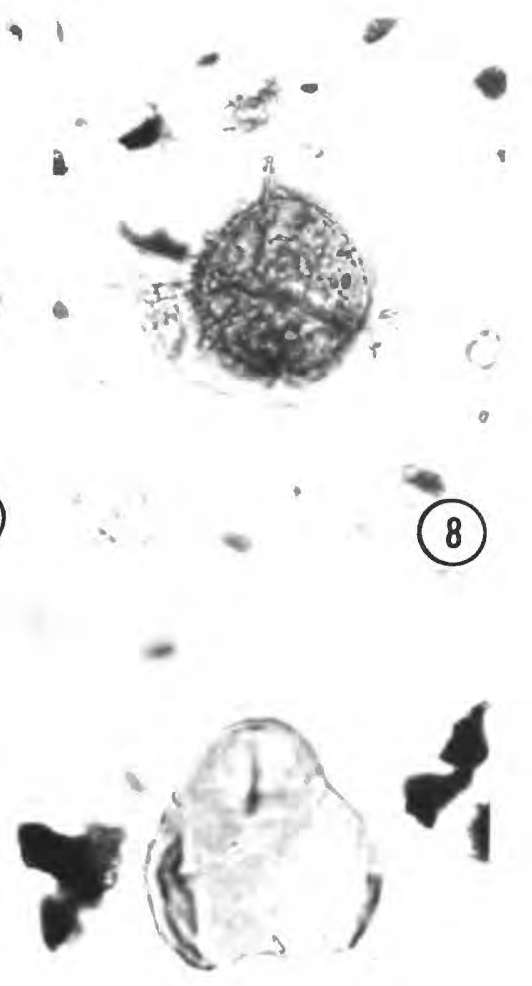

(10)

(11) 
Plate 4

All figures $1000 x$.

1. Cyathidites australis $(500 x)$, p. 46.

2. Deltoidospora hallii, p. 48 .

3. Deltoidospora juncta, p. 48 .

4. Deltoidospora juncta, p. 48 .

5. Deltoidospora psilostoma, p. 48 .

6. Densoisporites sp. A, p. 49.

7. Dictyophyllidites sp. A, p. 50.

8. Distalanulisporites verrucosus, p. 50 .

9. Distaltriangulisporites sp. A, p. 51 .

10. Foraminisporis sp. A, p. 52 .

11. Foveosporites subtriangularis, p. 52.

12. Gleicheniidites circinidites, p. 53. 

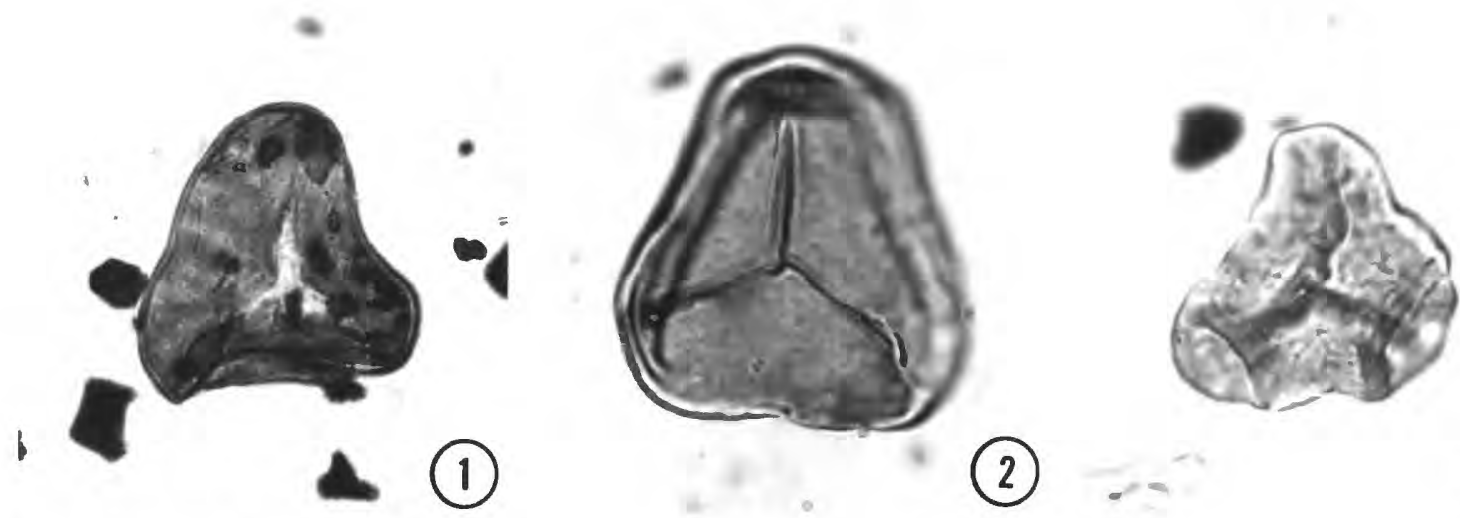

(2) $\ldots$

(3)
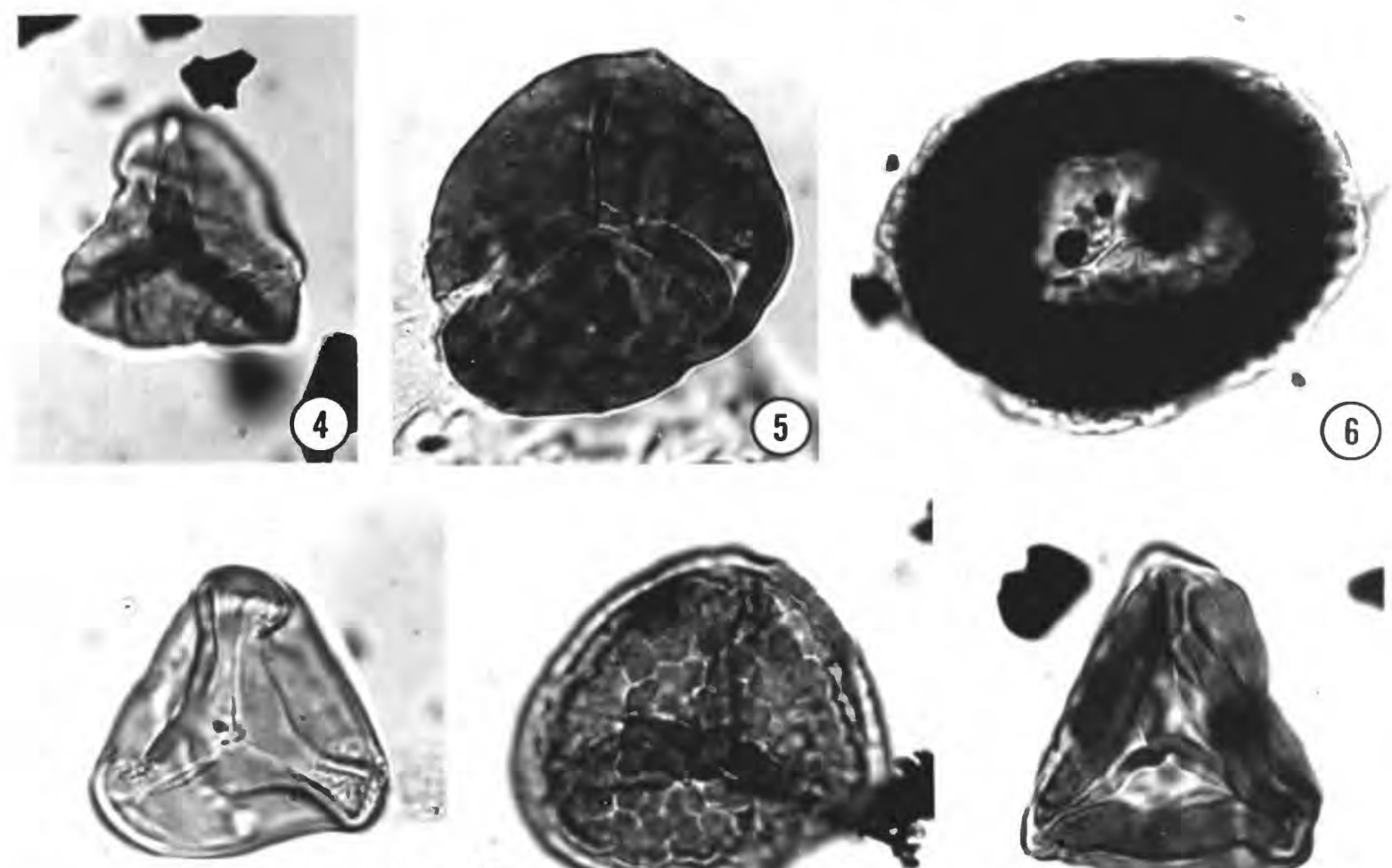

(7)
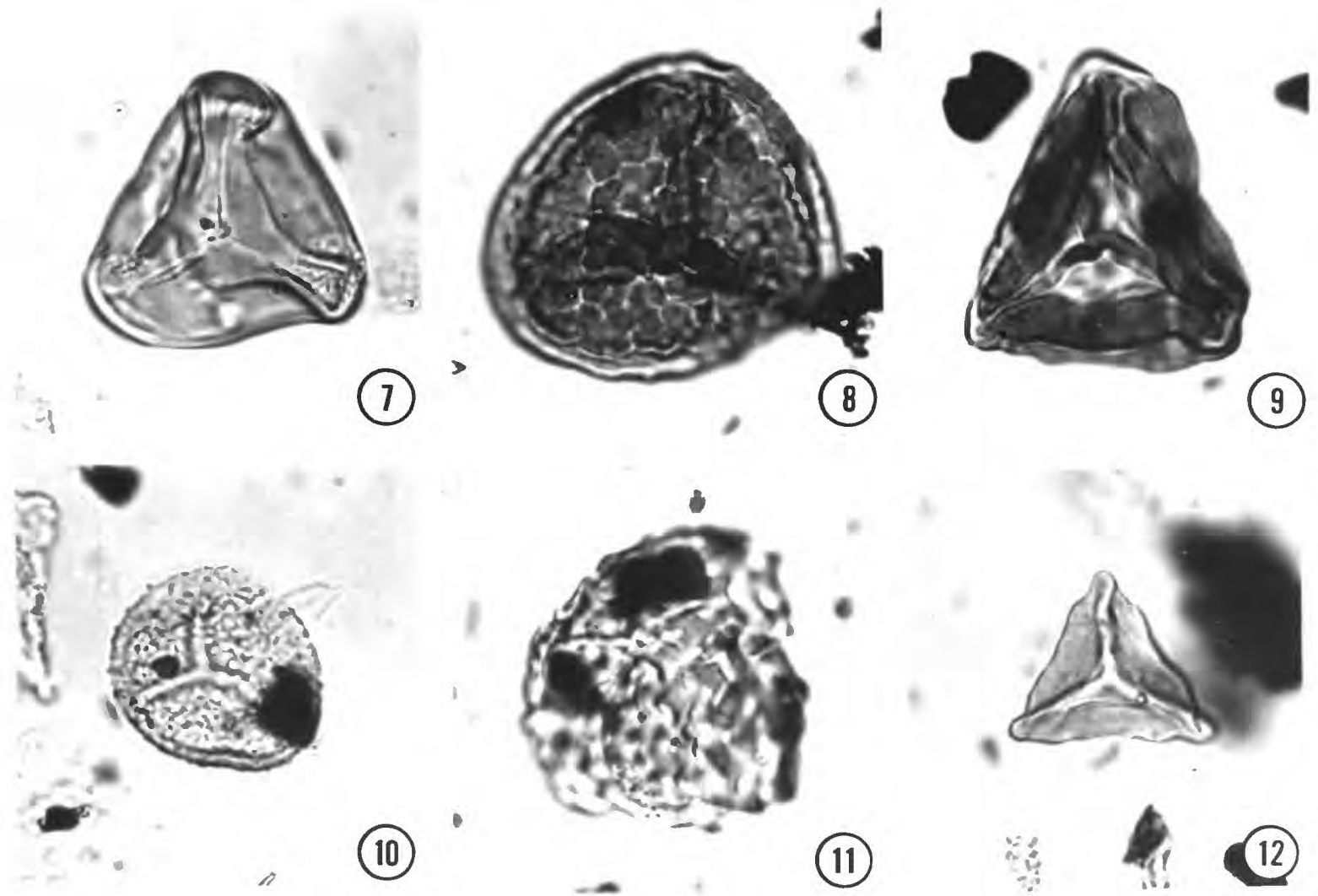
Plate 5

All figures $1000 x$ unless otberwise specified.

1. Gleicheniidites senonicus, p. 53.

2. Granulatisporites sp. A, p. 54 .

3. Impardecispora trioreticulatus (500x), p. 55.

4. Laevigatosporites ovatus, p. 56.

5. Leptolepidites $\mathrm{sp}$. cf. L. verrucatus, p. 56 .

6. Lycopodiacidites sp. A, p. 57.

7. Lycopodiumsporites austroclavatidites, p. 58 .

8. Lycopodiumsporites reticulumsporites, p. 59.

9. Neoraistrickia breviclavata, p. 60.

10. Neoraistrickia truncata, p. 61.

11. Lycopodiumsporites marginatus, p. 58.

12. Neoraistrickia sp. A (500x), p. 61. 

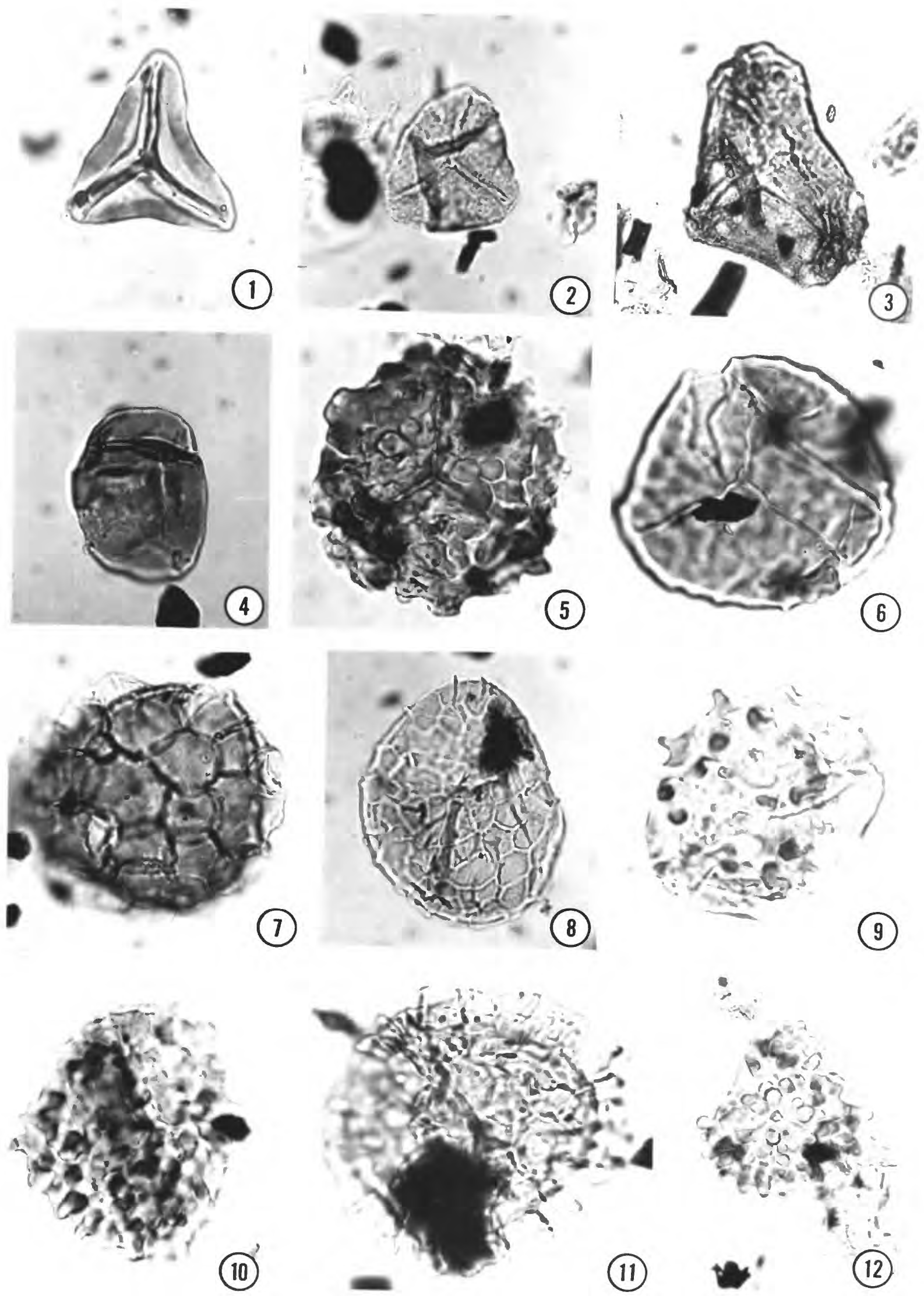

1

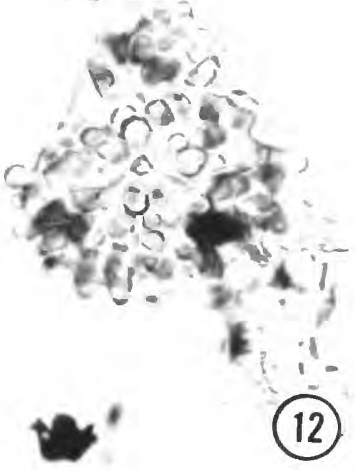


Plate 6

All figures 1000X.

1. Ornamentifera baculata, p. 62 .

2. Ornamentifera echinata, p. 63.

3. Osmundacidites wellmanii, p. 63.

4. Polycingulatisporites $\mathrm{sp}$. cf. P. reduncus, p. 64.

5. Rogalskaisporites cicatricosis, p. 65.

6. Sestrosporites sp. cf. S. pseudoalveolatus, p. 66.

7. Stereisporites antiquasporites, p. 66.

8. Tigrisporites sp. cf. T. reticulatus, p. 67 .

9. Todisporites minor, p. 68 .

10. Undulatisporites fossulatus, p. 68.

11. Verrucosisporites asymmetricus, p. 69.

12. Verrucosisporites sp. A, p. 70 . 

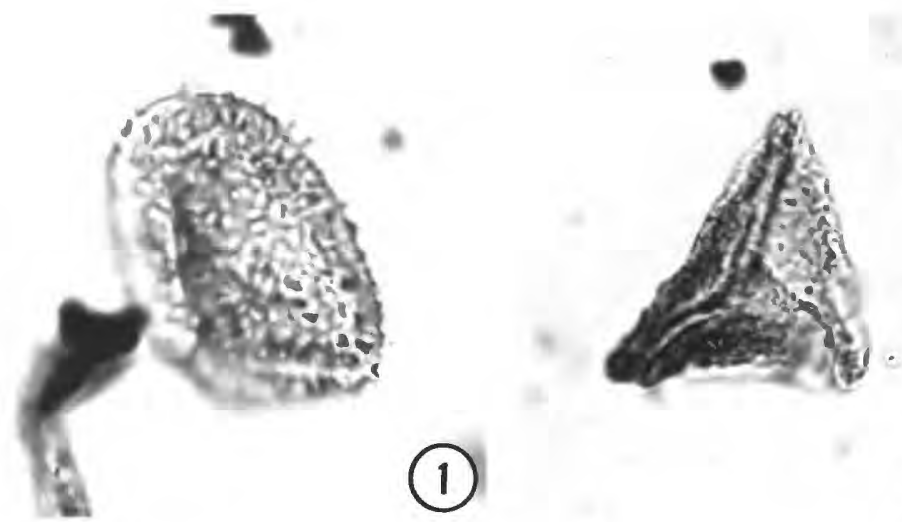

(2)

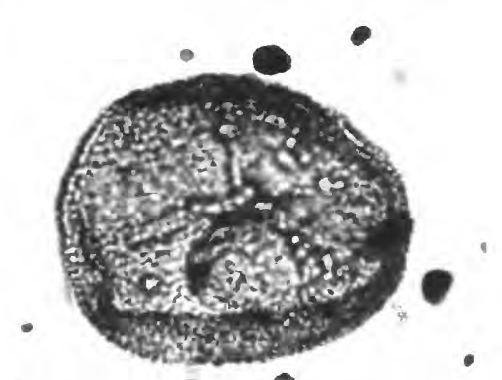

(1)
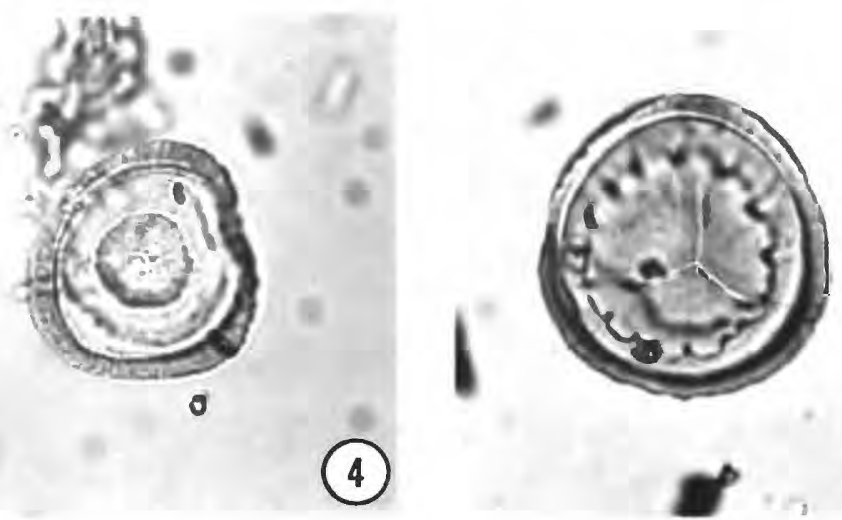

(4)

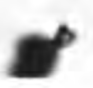

(5)
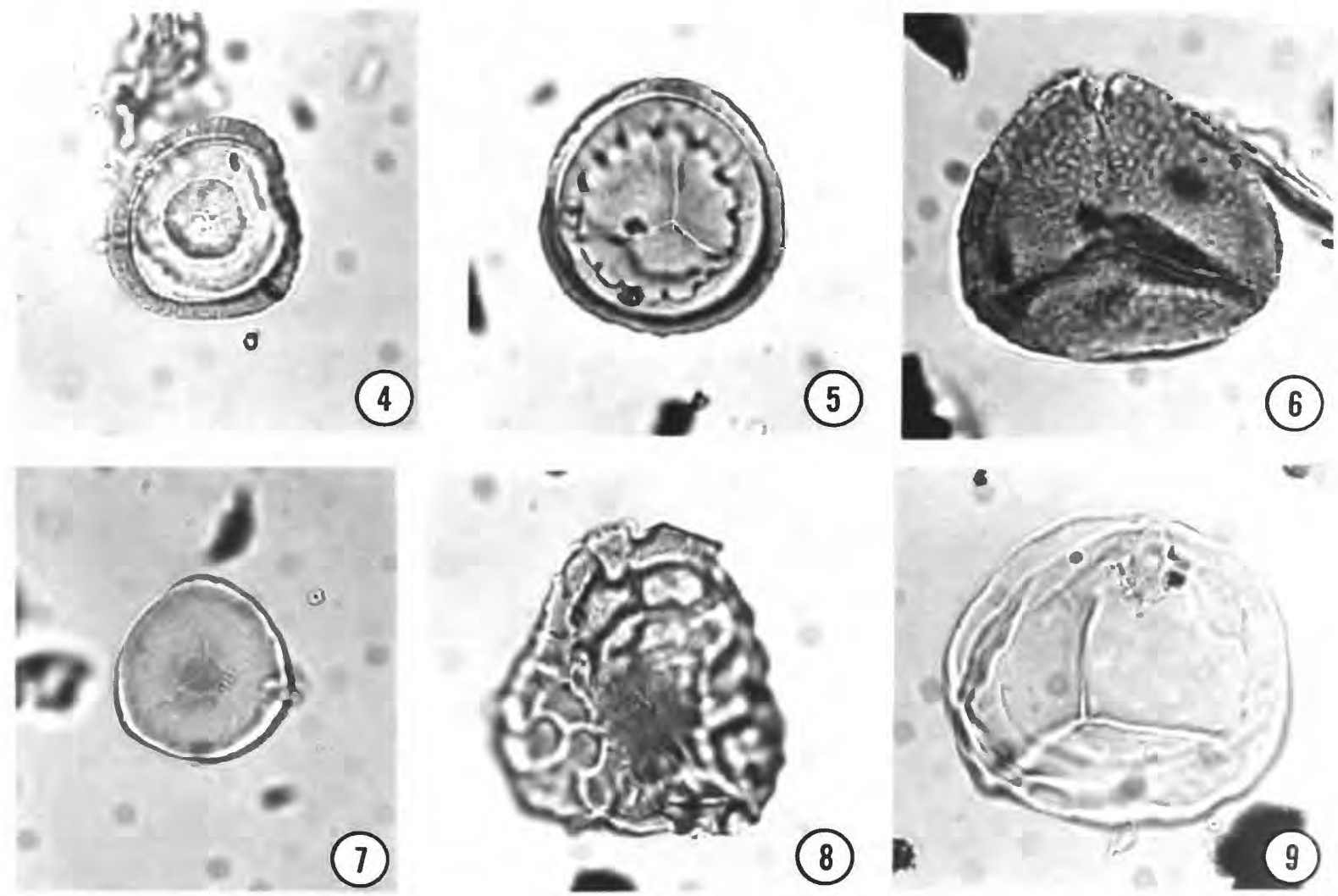

(8)
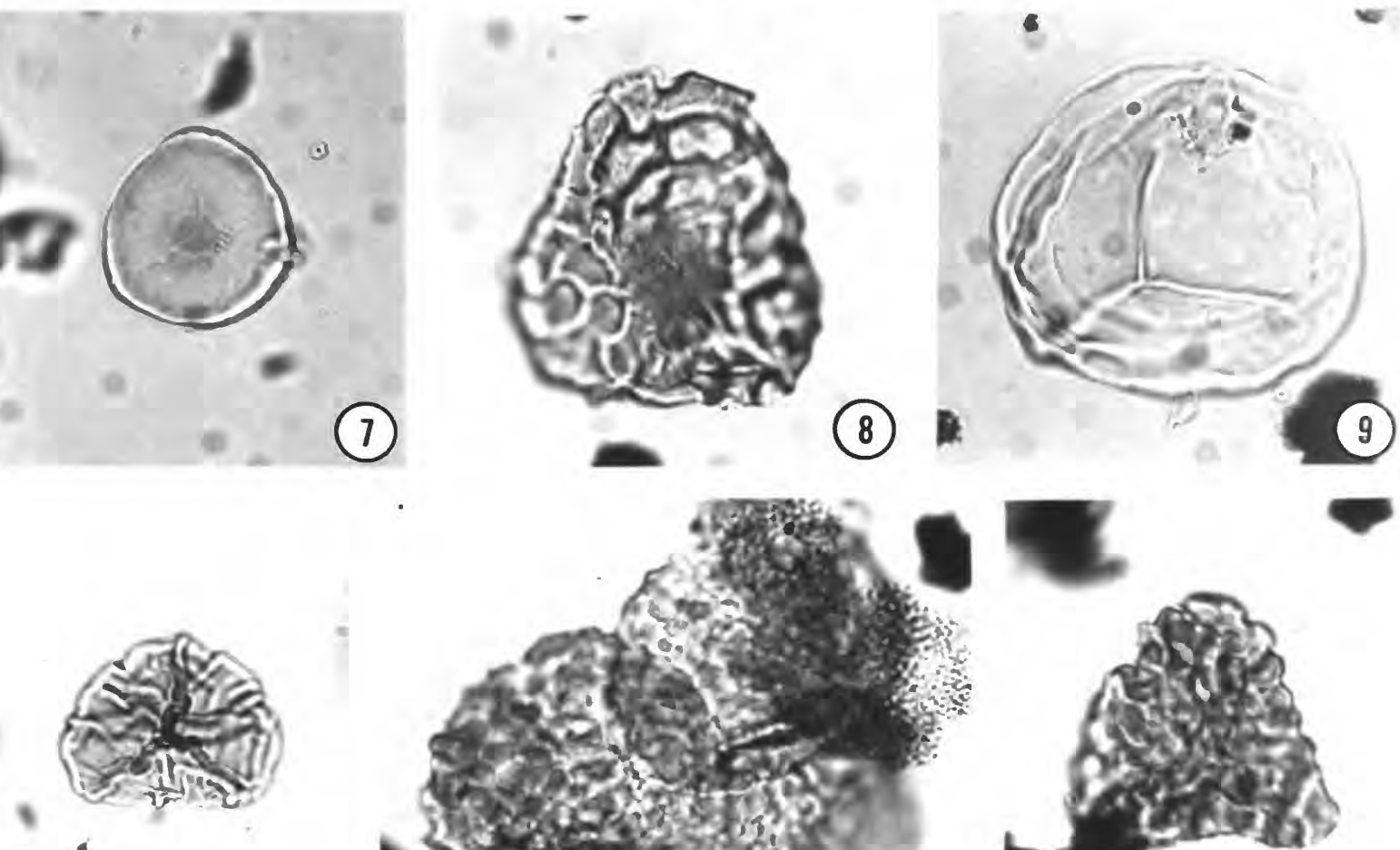

(10)
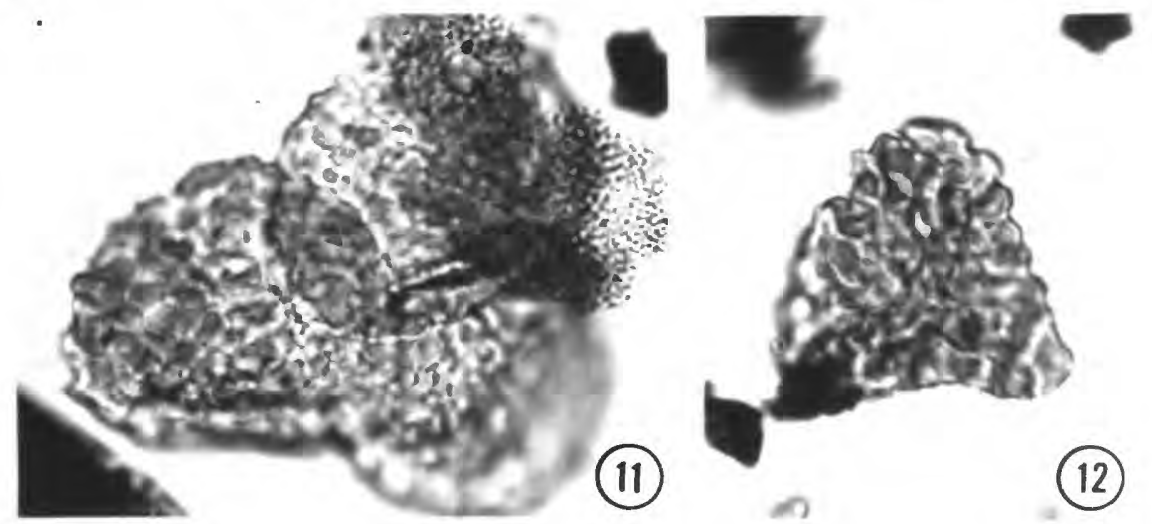